\title{
The Allure of Distant War Drums: Refugees, Geography, and Foreign Policy Preferences in Turkey*
}

\author{
Anna Getmansky ${ }^{\dagger} \quad$ Tolga Sinmazdemir ${ }^{\ddagger} \quad$ Thomas Zeitzoff $^{\S}$ \\ Accepted for publication in Political Geography
}

\begin{abstract}
Previous research argues that countries often intervene in the conflicts that cause refugees to flow across their borders. Public opinion against refugees may pressure states to intervene to 'solve the refugee problem.' We study what shapes public support for such intervention using a survey experiment in Turkey against the backdrop of the Syrian refugee crisis. We survey over 1,200 respondents with varied exposure to refugees, and randomize information about the consequences of hosting refugees to examine its effects on support for intervention in Syria. Emphasizing the negative externalities of hosting refugees, including their connection with militants, increases support for intervention among respondents who reside far from the Turkish-Syrian border. Closer to the border, this information reduces support for intervention in Syria. These findings highlight that vulnerability to the costs of intervention (proximity to the border) shapes public support for intervening. We also find that public opinion towards intervention is correlated with partisan identity and respondents' daily exposure to refugees.
\end{abstract}

WORD COUNT: 10,079 excluding Online Appendix (counted using TeXcount web service v.3.1.1)

\footnotetext{
${ }^{*}$ We are grateful to Amaney Jamal and the Mamdouha S. Bobst Center for Peace and Justice, as well as Helen Milner and the Niehaus Center for Globalization and Governance for their generous funding. This project was also supported by Bogazici University Research Fund (BAP) Grant Number 14C03SUP1. Finally, we would like to thank David Carter, Jacob N. Shapiro, and Empirical Studies of Conflict (ESOC) workshop participants for their helpful comments on an earlier experimental design.

${ }^{\dagger}$ London School of Economics and Political Science, a.getmansky@lse.ac.uk

${ }^{\ddagger}$ London School of Economics and Political Science, t.sinmazdemir@lse.ac.uk

${ }^{\S}$ American University, zeitzoff@american.edu
} 


\section{Introduction}

What factors influence support for intervention in civil wars? Previous research argues that refugees may lead a host country to intervene in a neighboring civil war (Salehyan, 2008). Some scholars argue that hosting refugees may impose negative externalities on the host society, ${ }^{1}$ which in turn increase public support for intervention to stem the flow of "externalities" (refugees) (Salehyan, 2008). Other research emphasizes the importance of partisan and ideological concerns (Berinsky, 2007, 2009; Saideman, 2012; Rathbun et al., 2016), and the odds of success (Gelpi, Feaver and Reifler, 2006).

Yet there are three major gaps in the understanding of how refugee flows may lead to increased support for intervention. First, it is unclear that there is a causal link between the arrival of refugees and fighting in the first place. It could be that refugee flows are correlated with other issues such as weak state borders that lead to spreading violence, and refugee presence is a sideeffect rather than a cause of conflict. ${ }^{2}$ Second, if refugees do increase support for intervention, then through what mechanisms does the presence of refugees influence attitudes- the perception that they lead to negative economic externalities, upsetting the host country's ethnic balance, or making the host country less safe)? ${ }^{3}$ Most of the previous research has studied the effects of refugee flows on conflict at an aggregate level (country-level), but assumes a micro-mechanism (individuals becoming prejudiced towards refugees). Finally, attitudes towards intervention are likely to vary based on respondents' distance from the border with Syria. Proximity to Syria can increase the likelihood of exposure to any potential fallout from intervention (Getmansky and Zeitzoff, 2014; Zeitzoff, 2014). For example, in Kosovo, NATO's aerial bombing of Serbian regime targets led-at least in the short term-to increased targeting of Kosovar refugees by the Serbian forces, and to additional outflows of refugees to neighboring countries (Roberts, 1999). In Iraq in 1991, intervention-the establishment of a safe zone in north of the country-resulted in a different

\footnotetext{
${ }^{1}$ These include increased competition over resources, disruption of the host country's ethnic balance, and possible arrival of individuals with combat experience intermingled among the refugees (Salehyan and Gleditsch, 2006).

${ }^{2}$ There is some evidence questioning refugees' presence as a source of contagion for conflict spread. See (Shaver and Zhou, 2015).

${ }^{3}$ For instance, Lazarev and Sharma (2017) finds that emphasizing the shared religion of Syrian refugees reduces prejudice of Turkish citizens, but priming related to economic costs of refugees negates this effect.
} 
outcome: it prevented the outflow of Kurdish refugees into the neighboring Turkey (Wolfe, 2017). Thus, it is possible for various foreign interventions to increase or prevent outflows of refugees from conflict area, thereby creating different preferences among the population in host country with respect to intervention. In addition to exposure to the consequences of conflict, respondents who reside by the border may exhibit more positive attitudes towards the refugees (Gravelle, 2014; Berezin and Díez-Medrano, 2008). In this paper, we advance our understanding of support for intervention by examining how exposure to the differential externalities of intervention influences attitudes and support for different modes of intervention. Do those that live near areas that are likely to experience the military fallout from intervention have different views on intervention, than those that do not? The distribution and regional variation in foreign policy attitudes, especially as it relates to the costs of foreign policy is an important, and understudied point.

We examine the public opinion foundation of these claims that states intervene to solve or stop a perceived refugee crisis. In particular we directly test the effects of different messages related to negative perceptions that locals might hold towards refugees. We test support for intervention in relation to the influx of Syrian refugees in Turkey, where approximately 4.9 million Syrians have fled the violence due to the Syrian Civil War and found refuge in the surrounding countries (UNHCR, 2014). Indeed, from August 2016 to March 2017, Turkey-a country that hosts the largest number of Syrian refugees-has intervened militarily in northern Syria against ISIS and Kurdish-backed militants. ${ }^{4}$ More recently, in January 2018, Turkey launched a second operation in northwestern Syria, called The Olive Branch, to take the city of Afrin from the Kurdish People's Protection Units' (YPG) control, and put it under the control of Turkish-backed opposition forces in Syria (Shaheen, 2018). Although the main aim of these operations was not the return of refugees to Syria, as a result of these two operations, about 300,00 Syrian refugees have returned and resettled in these de-facto buffer zones in northern Syria (Reuters, 2018).

Our design distinguishes between several different outcomes including: support for using force to remove the Syrian President Assad, using force to establish a 'safe zone' in northern Syria,

\footnotetext{
${ }^{4}$ Turkey's operation in Syria, called The Euphrates Shield, targeted ISIS and Kurdish militants, and led to the control of Jarablus and Al-Bab by Turkish-backed opposition forces (BBC, 2017)
} 
and support for less active intervention, such as assistance to Syrian rebels in general, and to the Islamic opposition in particular. ${ }^{5}$ We explore whether information about hosting refugees works differently on respondents who are more likely to be exposed to the potential fallout, or violent spillover of such intervention. To address these questions, we survey over 1,200 respondents in Turkey - a country that has received the largest number of Syrian refugees (UNHCR, 2014). ${ }^{6}$ Our survey was conducted in June 2014, and focuses on southeast Turkey, where the majority of refugees resided at that time. ${ }^{7}$ We randomize information about the potential consequences of hosting Syrian refugees, and examine how this information affects the support of the local population in Turkey for various forms of intervention that Turkey can undertake in Syria.

Overall, we find low support for active intervention in Syria (use of force as well as support for the Syrian opposition). ${ }^{8}$ The public opinion is divided on the general question of Turkey's involvement in this conflict: whereas 51\% support staying away from the Syrian conflict altogether, 35\% oppose this option (that is, favor some sort of involvement), and $14 \%$ are neutral on this question. Additionally, we find that negative information about refugees, and messages that emphasize their possible connection with militants, increase support for Turkish intervention in Syria, including the use of force by Turkey to establish a Safe Zone in northern Syria where these refugees could reside. Yet this effect is primarily driven by respondents who live far from the Turkish-Syrian border. Closer to the border, negative messages about refugees actually reduce support for intervention, or have no effect. Our findings suggest that vulnerability to the potential fallouts of Turkish intervention in Syria ${ }^{9}$ shapes how information about the externalities of hosting refugees affects support for intervention. Hence, the potential costs of intervention (which are expected to be more pronounced near the border) moderate the effects of our treatments. This is in line with previous studies that emphasize the importance of local costs of war (Gartner, Segura

\footnotetext{
${ }^{5}$ We also ask about the respondents' views on aligning with Assad or staying away from the conflict altogether.

${ }^{6}$ Syrian refugees are technically considered "under temporary protection" and not refugees by the Turkish government.

${ }^{7}$ We show below that our respondents vary significantly in their exposure to refugees.

${ }^{8}$ This is in line with the findings of other public opinion surveys in Turkey (Center for Economic and Foreign Policy Studies (EDAM), 2012; Acikmese and Unver, 2013; The German Marshall Fund of the United States, 2015).

${ }^{9}$ Although the risks of intervention in Syria may affect Turkey as a whole, they are more pronounced in some areas than in other. Even prior to the 2016 Turkish operation, the consequences of fighting in Syria-such as the shooting down of the Syrian plane (Butler, 2014) and the rocket fire from Syria into Turkey (Pamuk, 2014), were more strongly felt in border-adjacent areas than in places farther from the border.
} 
and Wilkening, 1997; Getmansky and Zeitzoff, 2014) and violence (Dube, Dube and García-Ponce, 2013). Far from the border, respondents are more supportive of intervention in the Syrian Civil War, and of measures that would stem future arrival of refugees (such as creating a safe zone), and this finding is consistent with the logic in Salehyan (2008).

We further demonstrate that our findings cannot be accounted by ethnic differences between border and non-border areas, or individuals at the border having more knowledge about or sympathy towards refugees. We also find strong partisan effects-the ruling AKP supporters are more in favor of intervention, whereas the main opposition's backers (CHP) are against it. Frequent exposure to refugees is also associated with a stronger support for intervention in Syria, regardless of the treatment. Exposure to past violence in the Turkish-Kurdish conflict is unrelated to intervention attitudes. Finally, we find weaker effects of ethnicity, with Turkish Kurds and Arabs slightly more in favor of intervention compared to non-minority Turks. Overall, messages about refugees do increase the support for intervention, but the vulnerability to its fallout (proximity to the border) moderates this effect.

In sum, our survey experiment and findings represent an important contribution to understanding how refugee presence shapes attitudes towards intervention for the following five reasons. 1) We do not simply ask about support for intervention, but rather present respondents with a suite of possible modes of intervention (e.g., establishing a safe zone, support Islamic opposition, etc.). ${ }^{10}$ 2) Our survey samples individuals with varying exposure to refugees and the conflict (closeness to the border), and to Turkish-Kurdish violence. 3) Perhaps most importantly, we also incorporate an experimental component by varying information about refugees to examine how it affects positions towards intervention. 4) In addition we employ various measures of proximity to the border with Syria-we compare border provinces and districts to those that are not by the border, and also directly measure the respondents' distance from the border. 5) Finally, we

\footnotetext{
${ }^{10}$ The other publicly-available surveys of Turkish attitudes towards intervention in Syria are Center for Economic and Foreign Policy Studies (EDAM) (2012); Acikmese and Unver (2013); The German Marshall Fund of the United States (2015). Only the Center for Economic and Foreign Policy Studies (EDAM) (2012) asks about support for using force against the Assad regime, but does not explicitly ask whether Turkey should use force to remove Assad. The overall low support for intervention in our survey is similar to the rate of support for intervention reported in these other surveys.
} 
explore and rule out alternative explanations for our findings, for example that respondents' ethnicity close to the border differs from the ethnicity of those far from the border. We do not find support for this in the data.

In the next section, we provide background about this case. Then, we review some relevant literature, and form hypotheses. Afterwards, we present our data and the empirical strategy, followed by results and summary.

\section{Turkey and the Syrian Civil War}

Turkey-Syria relations have historically been tense, ${ }^{11}$, but they improved significantly following the AKP's ascension to power in 2001, and included mutual visits at the highest levels, joint cabinet meetings, military drills, and a free trade agreement (Y1lmaz, 2013).

With the outbreak of violence in Syria in March 2011, Turkey urged Assad to introduce political, economic, and social reforms (Taşpınar, 2012; Yılmaz, 2013), but soon became disillusioned with the possibility of such changes (Yassin-Kassab, 2011). By the end of 2011, Turkey's Prime Minister at that time, Recep Tayyip Erdoğan, was openly calling for Assad's resignation (Arsu, 2011; Burch, 2011). He became a stout supporter of the anti-Assad opposition, hosting militants from the Free Syrian Army (Stack, 2011; Y1lmaz, 2013), and-according to some-even aiding more radical groups (Barkey, 2014) by allowing foreign jihadi fighters to cross from Turkey into Syria (Al-Shishani, 2013). In early 2012, Turkey called for a joint NATO intervention to establish a no-fly zone in northern Syria. NATO members, and especially the US, categorically ruled out military intervention, and Turkey turned to diplomatic channels to promote a political settlement, while clearly siding with and supporting the opposition in Syria (Y1lmaz, 2013). Some within Turkey, especially the Turkish Alawites who back the main Turkish opposition party CHP, have criticized

\footnotetext{
${ }^{11}$ The two countries had a territorial dispute over Turkey's Hatay province-a predominantly Arab region which was part of the French mandate in Syria after the First World War, and became a Turkish province in 1939 (Jorum, 2014 ; Yassin-Kassab, 2011). Syria also accused Turkey of diverting the Tigris and the Euphrates rivers' water for agricultural projects in southeastern Turkey (Olson, 1995). During the 1980s and 1990s, Syria supported the Kurdish separatists fighting against Turkey (the PKK), and provided a safe-haven in Syria for their leader, Abdullah Öcalan. In 1998, following Turkish diplomatic and military pressure, the Syrian government decided to cut off its ties with the Kurdish rebels, and expelled the PKK leader from Syria (Taşpınar, 2012).
} 
the alignment with the Sunni groups, and accused the government of engaging in a sectarian policy (Ifantis, 2013). Several CHP members of the Parliament even visited Damascus to express solidarity with Assad, and opposition to the Turkish intervention in Syria (Hürriyet Daily News, 2013; Y1lmaz, 2013). ${ }^{12}$

The Syrian conflict has also affected Turkish-Kurdish relations. Disenfranchised by the Syrian regime for decades, Syria's Kurds took advantage of the turmoil to establish control in predominantly Kurdish-populated territories in Northern Syria (close to the border with Turkey) (Ifantis, 2013; Y1lmaz, 2013). Unlike its policy towards the Sunni opposition, Turkey has refrained from supporting the Syrian Kurds against Assad because of the concern that their empowerment may embolden Kurds in Turkey to demand greater autonomy, especially given the close ties between the Kurds on both sides of the border. ${ }^{13}$

Turkey's opposition to the Assad regime, and its active support for the Sunni rebels in Syria resulted in a number of confrontations, making the Turkish territories along the border especially insecure. In the summer of 2012, the Syrian air defenses shot down a Turkish fighter jet near the border (Blair and Henderson, 2012). In October 2012, five Turkish civilians were killed by Syrian shells hitting the border town of Akçakale in Şanlıurfa province. In early 2013, NATO deployed batteries of Patriot missiles in Adana, Kahramanmaraş, and Gaziantep provinces in the southeast (North Atlantic Treaty Organization, 2013). In May of 2013, twin car bombings in Reyhanlı in the border province of Hatay that killed 52 people was blamed on the Syrian government by Turkish officials (Fahim and Arsu, 2013). ${ }^{14}$ In late 2014, Turkey allowed 150 Kurdish fighters with heavy weapons from North Iraq to cross through the Turkish territory by the border with Syria to fight ISIS in the besieged town of Kobanî (Yıld1z, 2016). ${ }^{15}$ In August 2016, Turkey intervened militarily

\footnotetext{
${ }^{12}$ The sectarian influence and the partisan differences in Turkish foreign policy towards Syria peaked with the killing of 52 civilians in a May 2013 bombing in Reyhanl - a Turkish border district that is home to a large Arab Alawite community with strong ties to the Syrian Alawites (Çağaptay, 2013). In response to this attack, Erdoğan highlighted that the fatalities were Sunni, and openly criticized the opposition party CHP and its leader for their relations with the Syrian regime (Letsch, 2013).

${ }^{13}$ Turkish and Syrian Kurds often share family connections, and the Syrian Kurdish movement (the PYD, and its military branch the YPG that is fighting in Syria) is a close ally if not a subsidiary organization of the PKK (Ifantis, 2013; Park, 2016).

${ }^{14}$ The suspects and motives for the attack still remain largely unknown.

${ }^{15}$ Unlike its opposition to the Kurdish Syrian PYD, Turkey adopts a more supportive approach towards the Kurdistan Regional Government (KRG) in Northern Iraq. This is, in part, because the KRG is critical of the PKK's presence in north
} 
in northern Syria against ISIS and Kurdish-backed militants (Shaheen, 2016). In January 2018, Turkey launched a second operation in northwestern Syria, called The Olive Branch, to take the city of Afrin from the Kurdish People's Protection Units' (YPG) control (Shaheen, 2018). Overall, these examples show that the Turkish areas close to the border with Syria have experienced some of the fallout of the fighting in Syria more than the areas that are remote from the border.

\section{Turkey and Syrian Refugees}

Syrian refugees started arriving in Turkey in April 2011. Their migration intensified with the escalation of violence in Syria. In response, the Turkish government opened several camps mostly in provinces along the border, to provide the refugees with food, healthcare, and education (see the map of camps in Figure A-1 in the Appendix). At the time of our survey, there were twenty two camps in ten provinces. ${ }^{16}$ Despite their number, the camps could accommodate less than a quarter of refugees that entered Turkey. The rest have settled outside among the local population predominantly in camp provinces in southeastern Turkey (UNHCR, 2014). ${ }^{17}$

Although initially Turkey adopted an 'open door' policy towards the Syrian refugees, in 2012 the government announced that it would not accept more than 100,000 Syrians ('red line'), and began proposing a safe zone in North Syria, where the refugees would return (Sanchez, 2012). The government has also tried to limit the number of refugees by assisting NGOs within Syria to manage camps for the internally displaced civilians, and by implementing a 'passage with careful control' (İçduygu, 2015, 7) to limit the entrance of individuals from some ethnic, religious, and ideological backgrounds. These measures, however, had little effect on the continuous inflow of refugees. The local population has also become increasingly discontent with the refugees' presence (Ferris, 2016): some blamed them for the increase in housing prices (Sak, 2014), the rise in unemployment, competition with local businesses (Çetingüleç, 2014; Güler, 2014), and even for social ills such as thefts, murders, smuggling, and prostitution (Erdoğan, 2015). The ethnic makeup of Iraq (Park, 2016; Y1ld1z, 2016).

${ }^{16}$ These provinces are Adana, Adıyaman, Gaziantep, Hatay, Kahramanmaraş, Kilis, Malatya, Mardin, Osmaniye, and Şanliurfa.

${ }^{17}$ According to the UNHCR data, on June 6, 2014 (one day before the beginning of our survey), about 749,000 of 900,000 refugees resided in provinces with camps, but only about 220,000 of them resided in camps (UNHCR, 2014). 
the host communities to a large extent predicts their attitudes towards the refugees: for example, areas in Hatay with predominantly Turkish-Alawite population (related to the Syrian Alawites) strongly opposed the settling of Sunni Syrians in their areas (ICG, 2013, 19-25).

Although the presence of Syrian refugees in Turkey is unprecedented in terms of their sheer numbers, Turkey has faced refugee influxes in the past which has led to significant political tensions. Most importantly, in 1991, after the Kurdish uprising against the regime of Saddam Hussein in Iraq failed, close to 500,000 Iraqi Kurds sought refuge in Turkey. Turkey admitted these refugees with great reluctance, and has immediately called for an international effort to create conditions for their return. One of the concerns of Turkish government was that the presence of Iraqi Kurds in Turkey could aggravate the domestic Kurdish conflict in Turkey (Kiriş̧̧i, 2000). As a result of Turkey's efforts in the international arena, a UN Security Council resolution was adopted, and a set of military and relief operations known as "Operation Provide Comfort" was launched. 11 countries participated in these operations, which led to the creation of a safe zone in Northern Iraq for Iraqi Kurds. In a way similar to the logic of the Turkish operations in northern Syria today, Turkish ruling elite was not pleased with the creation of this safe zone, because it allowed the Kurdish insurgent group PKK to operate from northern Iraq more easily (Kiriş̧̧i, 1996). However, it allowed the return of the great majority of the Kurds back to Iraq very quickly.

\section{Support for Intervention}

At the time of our survey, several options for Turkish foreign policy towards Syria were discussed. They ranged from intervening militarily to remove Assad, to establishing a safe zone in North Syria where the refugees and the displaced civilians could reside. Others favored more indirect involvement by supporting opposition groups such as the Free Syrian Army or Islamist/Islamic rebel groups (such as Al-Nusra Front). Finally, other options included staying away from the conflict altogether, or aligning with the Assad regime, as Turkey did before mid-2011. It is important to understand that these various policy options were discussed alongside the threat and occasional actual spill-over of violence from Syria into Turkey (especially in border areas), and in 
the context of a massive influx of refugees from the Syrian Civil War.

For the most part, Turkish public opinion has favored staying away from Syria, despite the growing discontent about the refugees' presence. Approximately 42 percent of the Turks supported neutrality and opposed any intervention in Syria in a nationally representative survey from November 2013, about 7 months before our survey (Acikmese and Unver, 2013). The second preference was assisting unarmed refugees (15 percent), followed by cutting commercial ties with Syria but not implementing any political or military sanctions. Only 9 percent favored participating in a multilateral intervention in Syria-an option that was considered a more remote possibility given the US opposition to introducing troops into Syria (Y1lmaz, 2013).

\section{Existing Literature and Hypotheses}

What influences support for intervention? Our paper synthesizes studies from three different literatures. First, the refugee-conflict literature examines how refugees presence may be associated with the spread of conflict both within and between states. Second, there is a lengthy literature, rooted mostly in U.S. foreign policy, that examines the dispositional and ideological factors on public opinion and the use of force. Finally, we also connect our research to a more recent literature on how exposure to potential negative externalities of a policy (i.e., the fallout from conflict) influences public support for it.

Previous research suggests that an influx of refugees may have negative externalities for host countries, and heighten the risk for conflict within the refugee-hosting state. Salehyan and Gleditsch (2006) propose three mechanisms through which refugees may spread conflict: they may expand rebel networks and bring arms, exacerbate economic competition over resources, or disrupt ethnic balance in their host societies. Several studies find a positive relationship between an influx of refugees and an increase in the likelihood of civil conflict in the host societies (Weiner, 1996; Whitaker, 2003; Lischer, 2005; Loescher and Milner, 2004; Forsberg, 2014; Milton, Spencer and Findley, 2013). ${ }^{18}$ Recent studies question this finding. Using sub-national data, these studies

\footnotetext{
${ }^{18}$ Additionally Choi and Salehyan (2013) find a positive correlation between refugees and terrorism, while Bove and
} 
fail to find a link between refugees' presence and onset of political violence (Fisk, 2014; Shaver and Zhou, 2015; Weidmann, Kuhn and Nikolic, 2007).

A large literature in economics suggests that the negative economic externalities of refugees and immigrants are overstated (Cortes, 2004), or non-existent (Card, 2005). Rather immigrants may be an economic boon to receiving countries as they can drive innovation (Hunt and GauthierLoiselle, 2010). ${ }^{19}$ In the context of Syrian refugees in Turkey, more recent research presents nuanced findings that Syrian refugees displaced low-skill, low-wage workers in Turkey, but also created new, high-wage jobs (Del Carpio and Wagner, 2015; Ceritoglu, Yunculer, Torun and Tumen, 2017).

In addition to intrastate instability, Salehyan (2008) argues that the arrival of refugees may spark conflicts between the host country and the country of origin. First, given the negative effect of refugees' presence, the host government may attempt to stem the flow of additional migrants by intervening in the conflict in their country of origin in order to end the civil war there, or to create safe zones that would prevent additional outflows of refugees. Second, the country of origin may pursue armed actors associated with the refugees, especially if some refugees are associated with rebels fighting against the government of their origin country. Furthermore, Greenhill (2011) provides evidence that actors (both state and non-state) may use the threat of a mass migration of refugees-and the negative externalities that may come with them-to coerce potential host states towards more favorable foreign policies.

We examine how the negative externalities of hosting the refugees influence support for military intervention in the refugee-causing conflict. Public opinion plays a crucial role in this calculus, as negative externalities associated with refugees may force politicians to take actions to stem their flow. For instance, Erdoğan and his then Foreign Minister Ahmet Davutoğlu repeatedly called for the creation of a safe zone in Northern Syria. They also lobbied U.S. to take the initiative for the Böhmelt (2016) only finds that this is true for migrants from terrorism-prone contexts.

${ }^{19}$ Additional research suggests that perceptions of refugees hurting local populations are incorrect (Kreibaum, 2016), and that they in fact can help local populations by attracting public assistance and improved public health outcomes (Tatah, Delbiso, Rodriguez-Llanes, Cuesta and Guha-Sapir, 2016; Betts, Bloom, Kaplan and Omata, 2017), and have positive spillovers to surrounding local economies (Taylor, Filipski, Alloush, Gupta, Valdes and Gonzalez-Estrada, 2016) 
creation of a safe zone, especially in the spring of 2013, when President Obama appeared to be considering a limited intervention in Syria (Al Jazeera, 2013). We expose individuals to information about different negative effects of refugees' presence, and evaluate how this information affects their positions on intervention. Following Salehyan (2008), we hypothesize that exposure to negative messages about refugees would increase the respondents' support for intervening in Syria, and especially support for policies that may stem additional flow of refugees, such as establishing safe zones in the country of origin (Hypothesis 1).

Earlier studies on American foreign policy attitude formation suggest that foreign policy attitudes are unprincipled and unstable, affected by emotions rather than reason (Morgenthau, 1978 cited in Holsti (1992)), and that the public follows cues from political leadership (Lipset, 1966 cited in Baum and Potter (2008)). This view began to shift during the Vietnam War towards an alternative theory that suggested that events related to foreign policy and to war shape public opinion. The most influential argument in this strand of literature is the 'casualty hypothesis,' according to which public support for war decreases as military casualties increase (Mueller, 1973 cited in Berinsky (2007)). Many studies, most of which use data from the US context, demonstrate the importance of local casualties in support for war (Gartner, Segura and Wilkening, 1997; Karol and Miguel, 2007). Other studies suggest that what is important is not the absolute number of casualties, but also the perceived stakes and the importance of the war goals (Larson, 1996). Building on this argument, Gelpi, Feaver and Reifler (2006) argue that the likelihood of success determines public support for conflict, and that the public will tolerate significant numbers of casualties if they believe in the rightness of war and the feasibility of success. Using data from the British context, Johns and Davies (2014) demonstrate that the public is more willing to support interventions when there is more international backing for this policy, and when the intervening country is part of a larger coalition rather than acts alone.

Proximity to border may also affect individual attitudes towards intervention. According to construal level theory, individual perception of close proximity events is very concrete and context specific, and it becomes more abstract when the distance between the individual and the event increases (Liberman and Trope, 2014). Concrete perception of events by the border can move indi- 
viduals either in favor or against cooperation, depending on the context. Exposure to terrorism in Israel (Getmansky and Zeitzoff, 2014) and Pakistan (Rehman and Vanin, 2017) strongly influences attitudes towards domestic and foreign policy. Similarly, proximity to the US-Mexican border increases support for border wall because respondents from these areas are directly exposed to such issues as illegal immigration, warning signs, and presence of security personnel (Gravelle, 2018) . This exposure heightens threat perception, and increases demand for border protection. Proximity to the border can also enhance support for cooperation. Respondents who reside close to a border with another European Union country are more supportive of integration (Berezin and Díez-Medrano, 2008), in part due to higher involvement in transnational networks and interactions (Kuhn, 2012). Proximity to border can also attenuate the effect of structural factors, such as partisanship as shown in the case of the US-Canada border, where proximity increases positive attitudes towards the neighboring country conditional on political identification (Gravelle, 2014). In sum, exposure due to distance to the positive or negative effects of a policy, and in particular conflict, are an important determinant of attitudes.

Based on this literature, we hypothesize that individuals close to the border should be less swayed by information on the negative effects of refugees (Hypothesis 2). We argue that proximity to border increases the chances of exposure to the costs of intervention (retaliation by the Syrian army or the rebels, additional inflow of refugees due to intervention). In the background section, we describe how violence in Syria sometimes spills over into Turkey, and affects near border areas (shooting down of the Turkish jet, mortar fire from Syria, and deployment of anti-missile batteries in border provinces, as we describe above) ${ }^{20}$ In addition, we examine whether the different effect in border areas is driven by warmer attitudes to refugees, or greater knowledge about the issue that weaken the treatment effects on those areas.

In addition to these two hypotheses, we control for a diverse set of variables that could provide alternative explanations for support for intervention. One key variable we control for is the respondent's partisanship. This is because previous literature-developed primarily in the context

\footnotetext{
${ }^{20}$ Other factors that affect opinion include exposure to refugees, socio-economic status, or ethnicity-all of which we control for in our regressions.
} 
of the US-suggests that elite cues shape public opinion on foreign policy. Using individual-level data from different periods in the US, Berinsky $(2007,2009)$ show that individuals rarely possess the information necessary to make cost/benefit calculations when forming their opinion on war. Instead, they follow cues from political elites. When politicians from different parties agree on the course of action, the public supports war. However, if there is no agreement between the major political players, then public opinion on war diverges along partisan lines. As we discuss in the background section, the AKP government at the time of our survey has been supportive of the Syrian opposition, and in favor of removing Assad; whereas the main opposition party (CHP) has been in favor of a more conciliatory approach towards Syria, prioritizing the end of the civil war over the removal of Assad. We include partisanship indicators to control for the effect of elite cues given the disagreement among the major parties in Turkey regarding the policy towards Syria.

Respondents' personal attributes can also affect their positions. For instance, income and education have been shown to increase support for extrovert foreign policy (Kertzer, 2013), and we control for these factors. Likewise, Rathbun et al. (2016) report that male gender and older age, as well as traditional values, are associated with militant internationalism. We therefore control for gender, age, and religiosity. Rathbun et al. (2016) also find that universal values are linked to cooperative attitudes and concern for all human beings. We distinguish between urban and rural dwellers because the former are more likely to be exposed to refugees (İçduygu, 2015). In addition, we control for respondents' exposure to refugees in their daily life, since contact with out-group has been hypothesized to affect attitudes towards members of those groups (Paluck, Green and Green, 2018). We also control for past exposure to conflict (residing in OHAL province) since it can also affect support for future conflict (Getmansky and Zeitzoff, 2014). Finally, respondents' ethnic identity can affect their position on intervention in Syria, since cross-border ethnic ties can influence individual views on policies that can affect their co-ethnics in other countries (Paquin and Saideman, 2017). Moreover, as discussed in the background section, a large number of Iraqi Kurdish refugees had returned from Turkey to a safe zone in northern Iraq in 1991, where PKK was able to operate with greater freedom (Kirişçi, 1996). Hence, in light of this past experience, our non-Kurdish respondents may consider the creation of a safe zone in Syria as a move that can 
potentially strengthen the Kurdish militant groups, including PKK and YPG. This is an additional reason for controlling for ethnic identity in the particular case of Turkish public opinion towards intervention in Syria.

\section{Research Design}

To test our hypotheses about how negative information of refugees (Hypothesis 1) and exposure to negative externalities from interventions (Hypothesis 2) influence support for intervention, we employ a survey experimental design in Turkey. This design offers several advantages. First, since previous research suggests that geography-both in terms of refugee exposure, and closeness to the Syrian border-is an important variable, our stratified sampling design allows to explicitly sample for this kind of variation. By exposing respondents to different primes related to the effects of refugees, we are able to causally test the effects of different proposed mechanisms of perceptions of refugees on support for intervention. This is important, since most previous studies in the refugeeconflict literature, while positing individual-level mechanisms, have examined the relationship between refugees and violence at a macro-level, and not at the individual-level, and furthermore not in a causally identified way.

\section{Sampling}

We randomly sampled districts using a stratified sampling procedure to produce variation on the key factors associated with support for intervention: refugee presence (exposure), past incumbent political support, and exposure to past violence associated with the Turkey-PKK conflict. ${ }^{21}$ Figure 1 shows the geographical distribution of our sample. The list of the provinces and districts, as well as the number of respondents in each district, is presented in Table A-1 in the Appendix. ${ }^{22}$

\footnotetext{
${ }^{21}$ It is important to point out that we explicitly did not attempt to create a national sample. By focusing on a narrower geographic region of Turkey (southeastern Turkey), we are better able to isolate the effect of variation in exposure to refugees and past violence. As an analogy, if one were studying the effects of immigration-our sample would be making comparisons about immigration exposure within Texas (regional), rather than between Montana and Texas (a national sample).

${ }^{22}$ Turkey is a unitary state divided into 81 provinces. Each province is composed of districts.
} 


\section{Sample Strata (districts)}

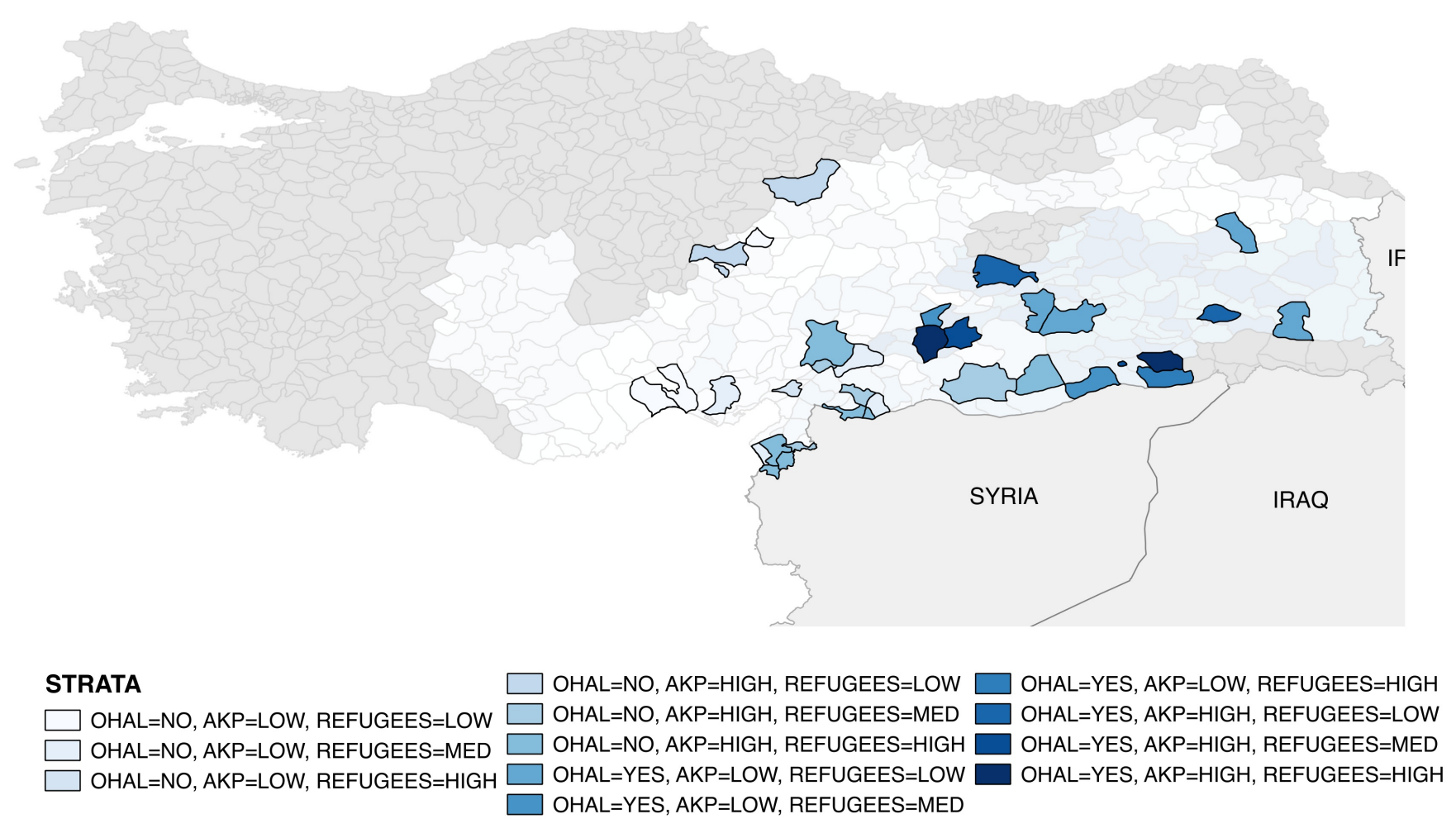

Figure 1: Map of the Sampled districts

The white areas represent our sampling frame, and the districts with dark borders are those where our survey took place. As the map and the strata legend show, our survey experiment involved respondents from a diverse set of districts - close to and far from the border; high, medium, and low level of refugee presence; high and low support for the incumbent; and high and low exposure to past violence. The definitions of high, medium, and low are in the Sampling subsection in the text. 
The survey was conducted face-to-face by a team of professional enumerators. We conducted training sessions with the enumerators to make sure they understand the survey and are comfortable executing it. Within each district, our enumerators chose a random starting point. They then randomly selected households, and individuals within each household with the most recent birthday were asked to participate in a survey about "current events." Households, not individuals were substituted.

Our sampling strategy resulted in surveying 1,257 subjects, and the response rate was $34 \% .^{23}$ Sample demographics are shown in Table 1. We report summary statistics for all the independent variables and their components separately for border and non-border provinces because we hypothesize that the effect of treatments may be different for individuals who reside close to Syria, and who may personally experience the potential negative effects of Turkish intervention.

Both the border and the non-border samples are well balanced on gender and across age groups. ${ }^{24}$ Our respondents from border and non-border provinces are also similar with respect to household income and religiosity. Non-border sample appears to be slightly more educated (38\% are college graduates compared to $31 \%$ among respondents from border provinces). About half of both border and non-border province respondents were AKP supporters. Support for the major opposition party, $\mathrm{CHP}$, is only slightly higher in border provinces (12\% of non-border and $15 \%$ of border province respondents identify as CHP supporters). This slight difference is due to the border province of Hatay, which is considered a CHP stronghold. In our regressions, we include province dummies to account for such province-level factors.

Border and non-border provinces differ in terms of their ethnic makeup: we have slightly more Kurdish respondents in non-border provinces ( $45 \%$ of the sample) than in border provinces (38\% of the sample). Likewise, border provinces have a higher percentage of Arab population, and this is reflected in our sample (23\% of border province respondents are Arabs compared to just $1 \%$ of non-border sample). There are also slightly more Alawites among the border province respon-

\footnotetext{
${ }^{23}$ We used American Association for Public Opinion Research (AAPOR) Response Rate 1 formula.

${ }^{24}$ Age group is coded on a 4-point scale, where (1) indicates the subject was 18-27 years old, (2) 28-37 years old, (3) 38-51 years old, and (4) 52 years or older.
} 
Table 1: Sample Demographics

\begin{tabular}{|c|c|c|c|c|c|c|c|c|c|c|}
\hline \multirow[b]{2}{*}{ Variable } & \multicolumn{5}{|c|}{ Non-Border Province $(N=777)$} & \multicolumn{5}{|c|}{ Border Province $(N=480)$} \\
\hline & $\mathrm{N}$ & Mean & $\begin{array}{l}\text { Std. } \\
\text { Dev. }\end{array}$ & Min & Max & $\mathrm{N}$ & Mean & $\begin{array}{l}\text { Std. } \\
\text { Dev. }\end{array}$ & Min & Max \\
\hline Female & 777 & 0.50 & 0.50 & 0 & 1 & 480 & 0.49 & 0.49 & 0 & 1 \\
\hline Age group & 777 & 2.44 & 1.09 & 1 & 4 & 480 & 2.43 & 1.10 & 1 & 4 \\
\hline Kurd & 777 & 0.45 & 0.50 & 0 & 1 & 480 & 0.38 & 0.49 & 0 & 1 \\
\hline Arab & 777 & 0.01 & 0.10 & 0 & 1 & 480 & 0.23 & 0.42 & 0 & 1 \\
\hline Alawite & 756 & 0.06 & 0.25 & 0 & 1 & 452 & 0.10 & 0.30 & 0 & 1 \\
\hline Urban District & 777 & 0.72 & 0.45 & 0 & 1 & 480 & 0.75 & 0.43 & 0 & 1 \\
\hline College graduate & 776 & 0.38 & 0.49 & 0 & 1 & 479 & 0.31 & 0.46 & 0 & 1 \\
\hline Household income & 737 & 5.00 & 2.80 & 1 & 16 & 460 & 4.97 & 2.47 & 1 & 16 \\
\hline AKP supporter & 718 & 0.50 & 0.50 & 0 & 1 & 457 & 0.52 & 0.50 & 0 & 1 \\
\hline CHP supporter & 718 & 0.12 & 0.33 & 0 & 1 & 457 & 0.15 & 0.35 & 0 & 1 \\
\hline MHP supporter & 718 & 0.13 & 0.33 & 0 & 1 & 457 & 0.06 & 0.23 & 0 & 1 \\
\hline Kurdish party supporter & 718 & 0.15 & 0.36 & 0 & 1 & 457 & 0.11 & 0.31 & 0 & 1 \\
\hline Ramadan survey & 777 & 0.14 & 0.35 & 0 & 1 & 480 & 0.04 & 0.20 & 0 & 1 \\
\hline \multicolumn{11}{|l|}{ Factor variables } \\
\hline Wealth & 777 & 0.43 & 0.32 & 0 & 1 & 480 & 0.40 & 0.29 & 0 & 1 \\
\hline Religious & 742 & 0.66 & 0.25 & 0 & 1 & 444 & 0.67 & 0.23 & 0 & 1 \\
\hline Refugee exposure & 736 & 0.46 & 0.34 & 0 & 1 & 463 & 0.59 & 0.23 & 0 & 1 \\
\hline \multicolumn{11}{|l|}{ Components of Wealth } \\
\hline Smart phone & 777 & 0.27 & 0.45 & 0 & 1 & 480 & 0.25 & 0.43 & 0 & 1 \\
\hline Car & 777 & 0.28 & 0.45 & 0 & 1 & 480 & 0.24 & 0.43 & 0 & 1 \\
\hline Computer & 777 & 0.43 & 0.50 & 0 & 1 & 480 & 0.35 & 0.48 & 0 & 1 \\
\hline Washing machine & 777 & 0.92 & 0.27 & 0 & 1 & 480 & 0.90 & 0.30 & 0 & 1 \\
\hline Dishwasher & 777 & 0.56 & 0.50 & 0 & 1 & 480 & 0.57 & 0.50 & 0 & 1 \\
\hline \multicolumn{11}{|c|}{ Components of Religious } \\
\hline Cover Hair & 759 & 0.77 & 0.33 & 0 & 1 & 476 & 0.72 & 0.28 & 0 & 1 \\
\hline Alcohol not OK & 770 & 0.57 & 0.44 & 0 & 1 & 478 & 0.61 & 0.36 & 0 & 1 \\
\hline Pray & 760 & 0.55 & 0.33 & 0 & 1 & 448 & 0.58 & 0.30 & 0 & 1 \\
\hline \multicolumn{11}{|c|}{ Components of self-reported Refugee Exposure } \\
\hline Public transport & 747 & 0.50 & 0.42 & 0 & 1 & 478 & 0.74 & 0.31 & 0 & 1 \\
\hline Street & 746 & 0.60 & 0.41 & 0 & 1 & 477 & 0.75 & 0.28 & 0 & 1 \\
\hline Business & 747 & 0.25 & 0.40 & 0 & 1 & 472 & 0.27 & 0.37 & 0 & 1 \\
\hline Social life & 743 & 0.39 & 0.42 & 0 & 1 & 468 & 0.48 & 0.38 & 0 & 1 \\
\hline Market & 745 & 0.53 & 0.42 & 0 & 1 & 474 & 0.68 & 0.32 & 0 & 1 \\
\hline
\end{tabular}


dents compared to non-border provinces sample (10\% and $6 \%$, respectively). ${ }^{25}$ Because of these differences, we control for ethnicity in all our regressions. Finally, border province respondents, unsurprisingly, report higher levels of exposure to refugees.

\section{Treatments}

Once a randomly selected person within a household agreed to participate, the survey proceeded as follows. First, subjects were asked basic demographic questions about their age, household size, and their community. Then the enumerators asked subjects several warm-up questions about how they are doing in general, and how they feel about the direction of Turkey. We then randomly assigned subjects to one of five experimental conditions described in Table 2, four of which were related to the Syrian refugee situation in Turkey. In the Control condition, subjects did not receive any information about the refugees. In the other four treatments, the enumerator read a brief statement heightening the salience of the refugees in Turkey, and then subjects received treatments (See Appendix for exact wording). The Economic Cost, Ethnic Balance, and Militant Ties treatments were all meant to reflect the key mechanisms through which refugees influence attitudes towards violence (Salehyan and Gleditsch, 2006). The Women and Children treatment was meant to balance out the negative tone of the treatments, with a more positive tone, and also to reflect AKP's justification of its open-door policy towards the refugees by calling the Syrian refugees Turkey's "brothers and sisters." ${ }^{26}$ It was also used to differentiate whether the negative aspects of the refugees (Economic Cost, Ethnic Balance, and Militant Ties), or simply mentioning the refugees

\footnotetext{
${ }^{25}$ Most Kurds, speak and understand Turkish as well as Kurdish. 97\% of the interviews were done in Turkish, and only 3\% of the interviews (43) were done in Kurdish. Instead of asking whether someone is a Kurd or not (i.e. binary classification), which is a sensitive question in Turkey, we asked how much each respondent identifies him/herself as Turkish, Kurdish, and as a member of other minority groups. We also asked about languages that respondents speak. Similar to previous studies of public opinion in Turkey (Yılmaz, 2014; Kalaycı̆̆lu and Çarkoğlu, 2007), we classify someone as Kurdish if they list their first language as Kurdish. There is a strong correlation between identifying as a Kurd and having Kurdish as the primary language $(\rho \approx 0.65)$. We also code whether a respondent is an Arab based on whether they list Arabic as their first language (9.5\% of our sample are Arabs). Finally, we also attempt to identify Alawite respondents, since Alawite identity may affect positions on foreign policy towards Syria. We code respondents as Alawites if they have Ali's picture in their house. Only 7.8\% of our sample are Alawites. See the Appendix for the exact wording behind these variables.

${ }^{26}$ See e.g. Idiz (2014).
} 
(Women and Children) influenced respondents' attitudes. ${ }^{27}$ Randomization checks are presented in the Appendix in Tables A-12 and A-13.

Table 2: Experimental Conditions

\begin{tabular}{|c|c|l|}
\hline Treatment & View on Refugees & \multicolumn{1}{c|}{ Description } \\
\hline Control & - & - \\
\hline Economic Cost & Negative & $\begin{array}{l}\text { Syrian refugees impose large costs } \\
\text { on government resources, and increase } \\
\text { unemployment among Turkish citizens. }\end{array}$ \\
\hline Ethnic Balance & Negative & Syrian refugees upset Turkey's ethnic balance. \\
\hline Militant Ties & Negative & $\begin{array}{l}\text { Syrian refugees have ties to militant groups } \\
\text { that make Turkey less safe. }\end{array}$ \\
\hline Women and Children & Positive & $\begin{array}{l}\text { Turkey's refugee policy has saved many innocent } \\
\text { women and children. }\end{array}$ \\
\hline
\end{tabular}

Following the treatment, the enumerators asked subjects their views on our main dependent variables: the possibility of Turkey 1) using force to remove Assad and 2) to establish a safe zone in northern Syria; 3) Turkey's support for all opposition in Syria or 4) only for the Islamic opposition; 5) the possibility that Turkey supports Assad; and 6) the option of staying away from the conflict altogether. Finally, we also asked subjects a series of questions about their contact and exposure to Syrian refugees and their religious views. ${ }^{28}$ Further information on the exact wording of specific items is included in the Appendix.

\section{Dependent variables}

We measure our variables of interest using six questions on the possible actions that Turkey can undertake in Syria: 1) use force to remove Assad; 2) use force to establish a safe zone in northern

\footnotetext{
${ }^{27}$ We might be concerned that our treatments are "double-barreled," in that we are priming both the refugees and a mechanism. However, we argue for two reasons that this is not problematic. First, our treatments are designed to mimic elite cues. Elite cues do not simply argue that refugees are a threat, but also usually point to why (e.g. stealing jobs, increasing rent, committing crimes, etc.). Finally, we would be concerned if we found that all of the treatments moved respondents in the same direction-then we would be unable to identify whether it was the refugee prime inherent in the treatments, or the different messages (mechanisms) about research which shifted attitudes. However, as we show in the Results section, the treatments have very different effects on attitudes suggesting that the mechanism matters, and that the treatments effectively are differentiated from one another.

${ }^{28}$ How often they pray, whether they believe that women should cover their hair, and their attitude towards alcohol.
} 
Syria; 3) support all opposition; 4) support Islamic opposition; 5) support Assad; and 6) stay away from the conflict. Respondents rank their support for each policy option on a scale from 1 (strongly oppose) to 7 (strongly support). Figure 2 presents the distribution of answers to these questions. This plot shows that the most preferred option is staying away (51\% support, $35 \%$ oppose, and $14 \%$ neutral). The next most favorable course of action is to use force to establish a safe zone in northern Syria (34\% support, $54 \%$ oppose, and $12 \%$ neutral). The least desirable option is for Turkey to support Assad (14\% support, 72\% oppose, and 14\% neutral). Public attitude is similar for support for Islamic opposition (25\% support, $64 \%$ oppose, and $11 \%$ neutral) and all opposition (21\% support, 64\% oppose, and 21\% neutral), as well as for using force to remove Assad (22\% support, $61 \%$ oppose, and $17 \%$ neutral).

The answers to these six questions are highly correlated $(\alpha=0.75)$, with all questions positively correlated, except for stay away (negatively correlated with the rest). To aggregate all these answers, we generate a new scale variable, Pro-intervention attitudes that combines responses to four questions (use force to remove Assad; use force to establish a safe zone in northern Syria; support all opposition; and support Islamic opposition). As we show in the Appendix, the responses to these questions are highly correlated ( $\alpha=0.87$, factor loadings above 0.8 ), which indicates that they capture the same phenomenon and represent actions that Turkey could take to change status quo in Syria. In the Appendix, we also present factor analysis of the six and of the four questions.

In our empirical tests, we focus on Pro-intervention attitudes as our main dependent variable, and in addition examine the effect of our treatments and the other independent variables of interest on each of the four questions separately. We rescale all dependent variables to lie between 0 and 1 to allow for easier interpretation.

\section{Estimation}

We are interested in how information about different potential effects of hosting the refugees (our treatments) affects the dependent variables while controlling for fundamental attributes partisanship, residing near the border, refugee exposure, past exposure to violence, and ethnicity. 
Figure 2: Responses to the Main Dependent Variables Questions

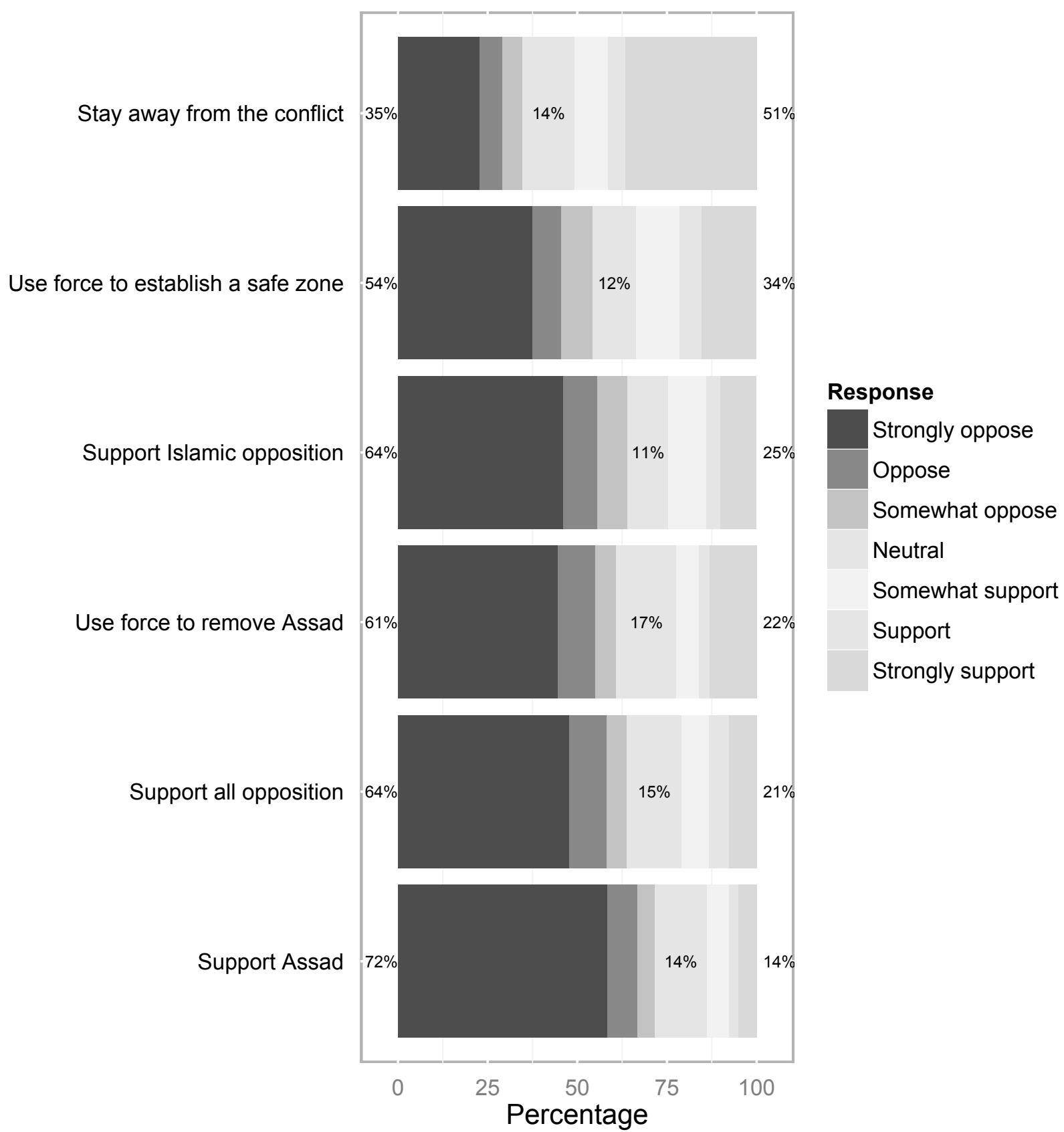

These plots represent the answers to our six questions on foreign policy options. The answers range from strongly oppose (1) to strongly support (7). The number on the left of each bar represents the percent of respondents who oppose the given action (responses 1,2, or 3); the number in the middle represents the percent of neutral responses (4); and the number on the right represents the percent of respondents who support the given action (responses 5, 6, or 7). 
Given that we hypothesize that intervention is likely to have a larger impact on individuals residing in border provinces, we interact our treatments with a dummy for residing in a border province. Our empirical specification for individual $i$ in province $j$ is the following OLS model:

$$
\begin{aligned}
Y_{i j} & =\alpha_{1} \times \boldsymbol{T}_{\mathbf{i}}+\alpha_{2} \times \text { Border }_{j}+\alpha_{3} \times \text { Border }_{j} \times \boldsymbol{T}_{\boldsymbol{i}} \\
& +\beta_{1} \times A K P_{i}+\beta_{2} \times \text { CHP }_{i}+\beta_{3} \times \text { MHP }_{i}+\beta_{4} \times \text { KurdishParty }_{i} \\
& +\beta_{5} \times \text { Refugee Exposure }_{i}+\beta_{6} \times \text { Kurd }_{i}+\beta_{7} \times \text { Arab }_{i}+\beta_{8} \times \text { Alawite }_{i} \\
& +\beta_{9} \times \text { OHAL }_{j}+\gamma \times \boldsymbol{X}_{\boldsymbol{i}}+\mu_{j}+\varepsilon_{i}
\end{aligned}
$$

where $Y_{i j}$ is the individual response to our dependent variables, $\mathbf{T}_{\mathbf{i}}$ is a vector of dummy variables which indicates which refugee treatment individual $i$ received; $B_{0 r d e r}$ is a dummy variable indicating whether the respondent resides in a border province; $A K P_{i}, C H P_{i}, M H P_{i}$ and KurdishParty $_{i}$ are dummy variables that indicates whether individual $i$ is an AKP, CHP, MHP, or Kurdish party supporter ${ }^{29}$, respectively (the omitted category are non-partisans or supporters of other parties); $\operatorname{Kurd}_{i}, \mathrm{Arab}_{i}$, and Alawite $_{i}$ are dummy variables that indicate whether respondent $i$ is a Kurd, an Arab, or an Alawite, respectively (the omitted category are non-minority Turks and other minority groups). $O H A L_{j}$ is a dummy variable equal to 1 if an individual lives in a former OHAL or adjacent zone province. $\mathbf{X}_{\mathbf{i}}$ is a vector of individual controls. ${ }^{30}$ We control for other province-level covariates by including a province-level dummy $\left(\mu_{j}\right) . \varepsilon_{i}$ is a normally distributed error. We allow for differential effects of the treatment for non-border respondents $\left(\alpha_{1}\right)$ versus border respondents $\left(\alpha_{1}+\alpha_{3}\right)$, to examine whether proximity to Syria moderates the effects of our treatment on support for intervention. We are also interested in the effect of the key observational variables $\left(\beta^{\prime}\right.$ s).

\footnotetext{
${ }^{29}$ We code supporters of Peoples' Democratic Party (HDP) and Peace and Democracy Party (BDP) together as Kurdish party supporters.

${ }^{30}$ It includes age group, religiosity index, college degree, wealth index, sex, dummies for urban resident and for whether the interview was conducted during Ramadan (only 10\% of the surveys were completed during Ramadan).
} 


\section{Main Results}

Below we test our two main hypotheses: (1) negative primes about Syrian refugees make local Turkish citizens more supportive of intervention in Syrian civil war; (2) negative primes affect respondents in non-border provinces differently from those in border provinces.

We begin estimating the effect of our treatments and observational variables of interest on Pro-intervention Attitudes - a scale variable composed of answers to four items that represent intervention to change the status quo in Syria (using force to remove Assad, using force to establish a safe zone in Northern Syria, supporting all opposition, and supporting the Islamic opposition). Table 3 presents four models that vary in the control variables and the province fixed effects that they include. We also asked the respondents about their support for a pro-Assad policy and for staying away from Syria altogether. The findings regarding these questions are in Table A-20 in the Appendix.

The Militant Ties treatment positively affects support for intervention in non-border provinces, whereas in border provinces the effect is negative (both effects are statistically significant, $p<$ 0.05). The Ethnic Balance treatment also increases support for intervention in Syria in non-border provinces, but only when we include control variables. Other treatments (economic cost of hosting the refugees, and saving innocent women and children) do not affect positions on intervention. The AKP supporters are more in favor of intervention, and the CHP supporters are less supportive of it. Kurds, and Alawites do not differ from non-minority Turks in their support for intervention, whereas Arabs are more supportive of intervention, but this result is marginally significant $(p<$ 0.1). Finally, higher exposure to refugees is associated with a stronger support for intervention in Syria.

In Table 4, we present the effects of our treatments on individual questions about intervention. The results show that our findings in Table 3 are driven primarily by responses to three questions: remove Assad, establish a safe zone in Northern Syria, and support all rebels. The Militant Ties treatment increases support in non-border provinces for this policies, and has the opposite effect on respondents from border provinces $(p<0.05)$. Support for the Islamic opposition in Syria is 
Table 3: Support for Changing Status Quo in Syria - Border vs. Non-Border Provinces

\begin{tabular}{|c|c|c|c|c|}
\hline & Model 1 & Model 2 & Model 3 & Model 4 \\
\hline \multirow[t]{2}{*}{ Economic Cost } & -0.011 & -0.016 & 0.002 & 0.009 \\
\hline & $(0.036)$ & $(0.033)$ & $(0.033)$ & $(0.034)$ \\
\hline \multirow[t]{2}{*}{ Ethnic Balance } & 0.048 & 0.048 & $0.068 * *$ & $0.070_{* *}$ \\
\hline & $(0.038)$ & $(0.034)$ & $(0.035)$ & $(0.035)$ \\
\hline \multirow[t]{2}{*}{ Militant Ties } & $0.075 * *$ & $0.077 * *$ & $0.095 * * *$ & $0.102 * * *$ \\
\hline & $(0.036)$ & $(0.033)$ & $(0.034)$ & $(0.034)$ \\
\hline \multirow[t]{2}{*}{ Women \& Children } & -0.021 & -0.018 & -0.005 & 0.002 \\
\hline & $(0.035)$ & $(0.030)$ & $(0.031)$ & $(0.031)$ \\
\hline \multirow[t]{2}{*}{ Economic Cost X Border Prov. } & -0.007 & -0.009 & -0.035 & -0.050 \\
\hline & $(0.054)$ & $(0.048)$ & $(0.050)$ & $(0.052)$ \\
\hline \multirow[t]{2}{*}{ Ethnic Balance X Border Prov. } & -0.050 & -0.053 & -0.074 & -0.074 \\
\hline & $(0.056)$ & $(0.050)$ & $(0.052)$ & $(0.054)$ \\
\hline \multirow[t]{2}{*}{ Militant Ties X Border Prov. } & $-0.141 * * *$ & $-0.143 * * *$ & $-0.173 * * *$ & $-0.173 * * *$ \\
\hline & $(0.054)$ & $(0.049)$ & $(0.052)$ & $(0.053)$ \\
\hline Women \& Children X Border & -0.007 & -0.011 & -0.035 & -0.035 \\
\hline Prov. & $(0.056)$ & $(0.049)$ & $(0.051)$ & $(0.053)$ \\
\hline \multirow{2}{*}{ Border Prov. } & 0.055 & 0.029 & -0.003 & -0.014 \\
\hline & $(0.038)$ & $(0.061)$ & $(0.067)$ & $(0.069)$ \\
\hline \multirow[t]{2}{*}{ OHAL } & & & 0.008 & 0.010 \\
\hline & & & $(0.082)$ & $(0.082)$ \\
\hline \multirow[t]{2}{*}{ Refugee Exposure } & & & $0.107 * * *$ & $0.106 * * *$ \\
\hline & & & $(0.037)$ & $(0.038)$ \\
\hline \multirow[t]{2}{*}{ Kurdish } & & & 0.058 & 0.048 \\
\hline & & & $(0.037)$ & $(0.037)$ \\
\hline \multirow[t]{2}{*}{ Arab } & & & $0.064 *$ & $0.062 *$ \\
\hline & & & $(0.033)$ & $(0.034)$ \\
\hline \multirow[t]{2}{*}{ Alawite } & & & -0.009 & -0.004 \\
\hline & & & $(0.033)$ & $(0.034)$ \\
\hline \multirow[t]{2}{*}{ CHP Supporter } & & & $-0.079 * *$ & $-0.062 *$ \\
\hline & & & $(0.031)$ & $(0.034)$ \\
\hline \multirow[t]{2}{*}{ MHP Supporter } & & & -0.017 & -0.012 \\
\hline & & & $(0.037)$ & $(0.038)$ \\
\hline \multirow[t]{2}{*}{ Kurdish Parties Supporter } & & & -0.049 & -0.042 \\
\hline & & & $(0.033)$ & $(0.032)$ \\
\hline \multirow[t]{2}{*}{ AKP Supporter } & & & $0.062 * * *$ & $0.066 * * *$ \\
\hline & & & $(0.023)$ & $(0.024)$ \\
\hline \multirow[t]{2}{*}{ Constant } & $0.306 * * *$ & $0.277 * * *$ & $0.203 * * *$ & $0.273 * * *$ \\
\hline & $(0.025)$ & $(0.035)$ & $(0.045)$ & $(0.056)$ \\
\hline Province Fixed Effects & No & Yes & Yes & Yes \\
\hline Additional Controls & No & No & No & Yes \\
\hline Observations & 1200 & 1200 & 1109 & 1077 \\
\hline R-squared & 0.01 & 0.20 & 0.23 & 0.24 \\
\hline
\end{tabular}

Dependent variable: Support for changing status quo in Syria (0-1). Higher values indicate greater support for intervention. Scale composed of oppose vs. support removing Assad, creating a safe zone in nothern Syria, supporting all rebel forces, and supporting only Islamic rebel forces. Additional controls are age, religiosity index, education, wealth index, sex, dummies for urban resident and for whether the interview was conducted during Ramadan (only 10\%). Robust standard errors in parentheses. Signif.: $* 10 \% * * 5 \% * * * 1 \%$. 
not affected by our treatments. In addition, our Economic Cost and Women and Children treatments do not affect attitudes towards different forms of intervention.

Moving onto our non-experimental variables, we find that partisan identity is also correlated with positions on intervention: the AKP supporters are more likely to be in favor of establishing a safe zone, supporting all rebels as well as the Islamic opposition. The CHP supporters are less supportive of using force to remove Assad or to establish a safe zone. We also find some evidence that ethnicity is correlated with positions: Arab respondents are more in favor of supporting the Islamic opposition while Kurdish respondents are more in favor of supporting all as well as Islamic opposition. In contrast to our expectations based on the establishment of a safe zone for Iraqi Kurdish refugees in 1991, Kurdish respondents are not less likely to support the establishment of a safe zone in Syria. Finally, refugee exposure is positively correlated with support for all types of intervention. Only in the case of establishing a safe zone, it barely misses significance at 10 percent (p-value is .12).

Figure 3 (a bootstrapped coefficient plot) demonstrates that our findings are substantively meaningful. In non-border provinces, the Militant Ties and the Ethnic Balance increase support for intervention by 10 and 7 percentage points, respectively (95\% significance level). AKP supporters and Arab respondents, and those who report higher exposure to refugees in their daily life are also more likely to support intervention $(7,6$, and 11 percentage points increase, respectively). The effect of Militant Ties treatment in non-border provinces is thus comparable in magnitude to the effect of partisanship. In border provinces, the Militant Ties treatment reduces support for intervention by about 7 percentage points, but this effect is significant only at $90 \%$ significance level.

The coefficient plots for the individual items (remove Assad, safe zone, support all rebels, and support the Islamic opposition) are in the Appendix (Figures A-2 through A-5), and they are consistent with the findings in Table 4. The Militant Ties treatment has a positive effect in nonborder provinces for removing Assad, establishing a safe zone, and supporting all rebels (but not Islamic rebels specifically). In border provinces, this treatment has a negative effect, but it is statistically significant only for support of using force to establish a safe zone in Northern Syria. 
Table 4: Support for Specific Policies of Intervention - Border vs. Non-Border Provinces

\begin{tabular}{|c|c|c|c|c|}
\hline & Remove Assad & Safe Zone & All Rebels & Islamic Rebels \\
\hline \multirow[t]{2}{*}{ Economic Cost } & 0.019 & -0.003 & 0.018 & 0.009 \\
\hline & $(0.041)$ & $(0.042)$ & $(0.038)$ & $(0.039)$ \\
\hline \multirow[t]{2}{*}{ Ethnic Balance } & $0.096 * *$ & $0.087 * *$ & 0.055 & 0.045 \\
\hline & $(0.042)$ & $(0.044)$ & $(0.039)$ & $(0.040)$ \\
\hline \multirow[t]{2}{*}{ Militant Ties } & $0.103 * *$ & $0.164 * * *$ & $0.111 * * *$ & 0.042 \\
\hline & $(0.042)$ & $(0.042)$ & $(0.040)$ & $(0.041)$ \\
\hline \multirow[t]{2}{*}{ Women \& Children } & 0.027 & 0.007 & -0.001 & -0.007 \\
\hline & $(0.040)$ & $(0.040)$ & $(0.035)$ & $(0.037)$ \\
\hline \multirow[t]{2}{*}{ Economic Cost X Border Prov. } & -0.039 & -0.039 & -0.075 & -0.049 \\
\hline & $(0.065)$ & $(0.068)$ & $(0.058)$ & $(0.062)$ \\
\hline \multirow[t]{2}{*}{ Ethnic Balance X Border Prov. } & -0.076 & $-0.131 *$ & -0.033 & -0.029 \\
\hline & $(0.066)$ & $(0.069)$ & $(0.063)$ & $(0.064)$ \\
\hline \multirow[t]{2}{*}{ Militant Ties X Border Prov. } & $-0.170 * * *$ & $-0.274 * * *$ & $-0.167 * * *$ & -0.048 \\
\hline & $(0.065)$ & $(0.069)$ & $(0.063)$ & $(0.065)$ \\
\hline Women \& Children X Border & -0.042 & -0.077 & -0.018 & -0.015 \\
\hline Prov. & $(0.066)$ & $(0.067)$ & $(0.060)$ & $(0.062)$ \\
\hline \multirow[t]{2}{*}{ Border Prov. } & -0.017 & -0.003 & -0.013 & -0.007 \\
\hline & $(0.083)$ & $(0.083)$ & $(0.075)$ & $(0.078)$ \\
\hline \multirow[t]{2}{*}{ OHAL } & 0.099 & -0.016 & -0.023 & -0.040 \\
\hline & $(0.090)$ & $(0.090)$ & $(0.099)$ & $(0.097)$ \\
\hline \multirow[t]{2}{*}{ Refugee Exposure } & $0.141 * * *$ & 0.077 & $0.090 *$ & $0.106 * *$ \\
\hline & $(0.050)$ & $(0.050)$ & $(0.047)$ & $(0.047)$ \\
\hline \multirow[t]{2}{*}{ Kurdish } & -0.027 & -0.003 & $0.090 * *$ & $0.132 * * *$ \\
\hline & $(0.043)$ & $(0.046)$ & $(0.045)$ & $(0.044)$ \\
\hline \multirow[t]{2}{*}{ Arab } & 0.037 & 0.036 & $0.068 *$ & $0.105 * *$ \\
\hline & $(0.043)$ & $(0.050)$ & $(0.041)$ & $(0.041)$ \\
\hline \multirow[t]{2}{*}{ Alawite } & 0.047 & 0.019 & -0.053 & -0.030 \\
\hline & $(0.044)$ & $(0.045)$ & $(0.040)$ & $(0.041)$ \\
\hline \multirow[t]{2}{*}{ CHP Supporter } & $-0.103 * * *$ & $-0.076 *$ & -0.045 & -0.016 \\
\hline & $(0.039)$ & $(0.043)$ & $(0.037)$ & $(0.039)$ \\
\hline \multirow[t]{2}{*}{ MHP Supporter } & -0.039 & 0.007 & -0.013 & 0.004 \\
\hline & $(0.044)$ & $(0.049)$ & $(0.044)$ & $(0.043)$ \\
\hline \multirow[t]{2}{*}{ Kurdish Parties Supporter } & $-0.072 *$ & -0.032 & -0.013 & -0.042 \\
\hline & $(0.042)$ & $(0.043)$ & $(0.037)$ & $(0.039)$ \\
\hline \multirow[t]{2}{*}{ AKP Supporter } & 0.045 & $0.077 * *$ & $0.079 * * *$ & $0.066 * *$ \\
\hline & $(0.030)$ & $(0.030)$ & $(0.028)$ & $(0.029)$ \\
\hline \multirow[t]{2}{*}{ Constant } & $0.310 * * *$ & $0.340 * * *$ & $0.229 * * *$ & $0.174 * * *$ \\
\hline & $(0.070)$ & $(0.073)$ & $(0.065)$ & $(0.067)$ \\
\hline Province Fixed Effects & Yes & Yes & Yes & Yes \\
\hline Additional Controls & Yes & Yes & Yes & Yes \\
\hline Observations & 1063 & 1061 & 1041 & 1031 \\
\hline R-squared & 0.16 & 0.18 & 0.19 & 0.26 \\
\hline
\end{tabular}

Dependent variables (0-1): Support for removing Assad (col. 1), creating a safe zone (col. 2), all rebel forces (col. 3), Islamic rebel forces (col. 4), All models include province fixed effects and additional controls: age, religiosity index, education, wealth index, sex, dummies for urban resident and for whether the interview was conducted during Ramadan (only 10\%). Robust standard errors in parentheses. Signif.: $* 10 \% * * 5 \%$ $* * * 1 \%$. 
Figure 3: Support for Intervention in Syria - Border / Non-Border Provinces Comparison

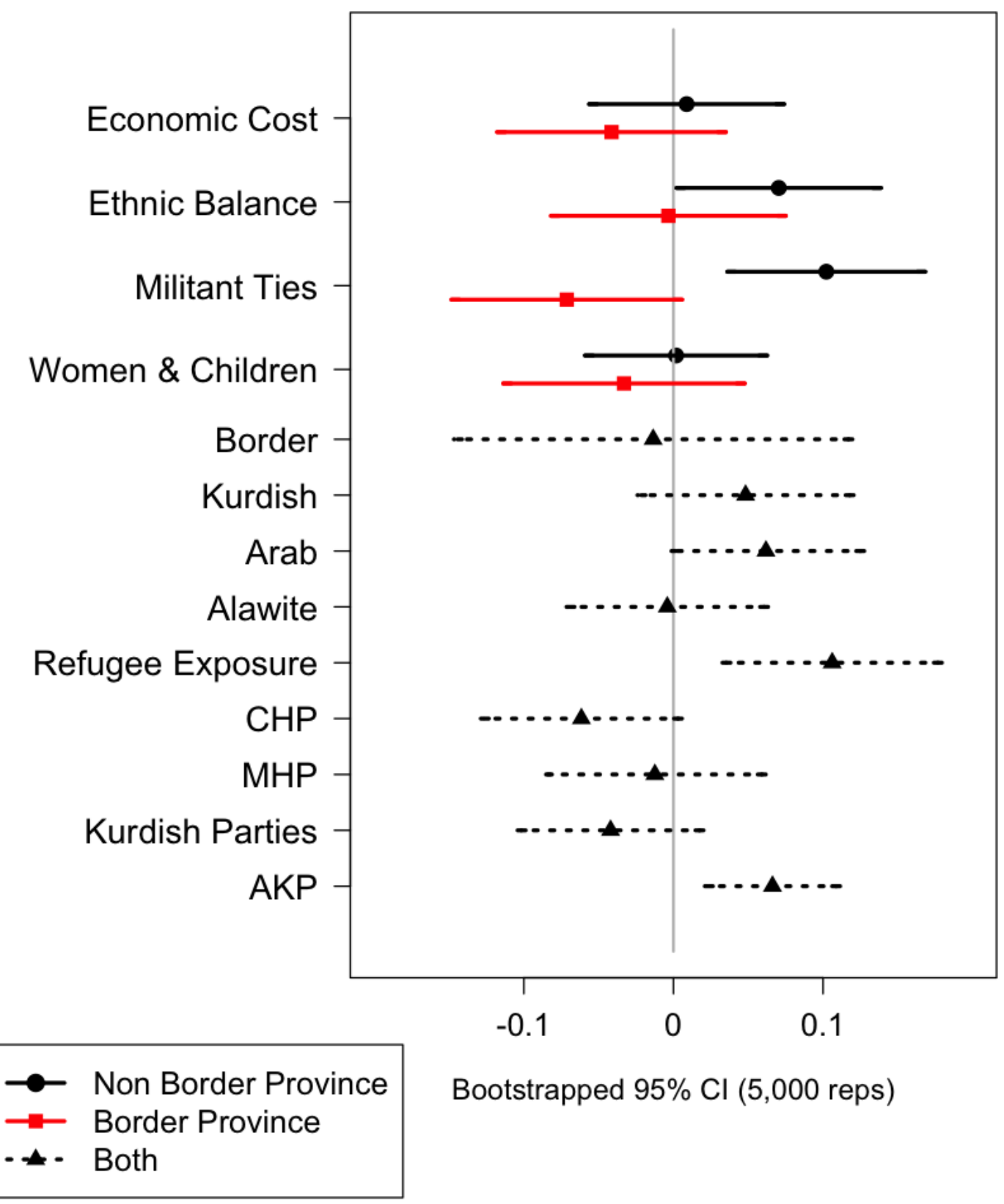


This finding is particularly interesting because such a safe zone would be across the border from the respondents who oppose. Furthermore, the Ethnic Balance treatment also has a positive effect on support in non-border provinces for removing Assad and for establishing a safe zone in Syria, and it does not affect positions among respondents from border provinces. Partisan identification is also correlated with some positions: AKP supporters are more in favor of safe zone, support for all rebels and for Islamic opposition. CHP supporters are against removing Assad.

\section{Support for Intervention and Distance from the Border}

In this section, we explore whether the effect of our treatments varies by distance to the nearest border crossing, ${ }^{31}$ to make sure the differential effect of the Militant Ties treatment in border and non-border provinces is robust to alternative measures of proximity to border. Using the Geographic Information System (GIS) software, we identified the nearest crossing to each of the districts in our sample, and calculated the shortest distance in kilometers between the centroid of each district and its nearest crossing. As Figure 1 shows, our sample is diverse in terms of distance from border crossings: a quarter of our respondents resides within 32 kilometers of a border crossing, and the median distance to the border is about 95 kilometers. We use proximity to border crossings because one of the potential fallout of intervention is an additional influx of refugees. This may affect areas closer to crossings more than other areas. In Table A-14 in the Appendix, we present results using the shortest Euclidean distance to the border with Syria (and not to a border crossings). The substantive results remain the same.

We interact each of our treatment indicators with the log of distance to the border in kilometers. In Table 5, we first report the findings regarding the scale dependent variable Pro-intervention Attitudes, followed by our results for the individual items. Overall, they are consistent with our main results using border province dummies: the Militant Ties treatment makes respondents residing farther away from the border more supportive of intervention, whereas the effect on those residing closer to the border is negative.

\footnotetext{
${ }^{31}$ Location of border crossings are from US Department of State (2015).
} 
Table 5: Support for Intervention - Distance to the Nearest Border Crossing with Syria in km (log)

\begin{tabular}{|c|c|c|c|c|c|}
\hline & Change SQ & Remove Assad & Safe Zone & All Rebels & Islamic Rebels \\
\hline \multirow[t]{2}{*}{ Economic Cost } & -0.053 & -0.039 & -0.031 & -0.098 & -0.019 \\
\hline & $(0.125)$ & $(0.150)$ & $(0.160)$ & $(0.133)$ & $(0.142)$ \\
\hline \multirow[t]{2}{*}{ Ethnic Balance } & -0.010 & 0.016 & -0.100 & 0.027 & 0.069 \\
\hline & $(0.126)$ & $(0.149)$ & $(0.162)$ & $(0.145)$ & (0.139) \\
\hline \multirow[t]{2}{*}{ Militant Ties } & $-0.214 *$ & -0.205 & $-0.284 *$ & $-0.230 *$ & -0.036 \\
\hline & $(0.115)$ & $(0.139)$ & $(0.154)$ & $(0.138)$ & $(0.135)$ \\
\hline \multirow[t]{2}{*}{ Women \& Children } & -0.044 & -0.020 & -0.144 & -0.075 & 0.032 \\
\hline & $(0.123)$ & $(0.143)$ & $(0.153)$ & $(0.136)$ & $(0.135)$ \\
\hline \multirow[t]{2}{*}{ Economic Cost X Distance } & 0.009 & 0.009 & 0.003 & 0.020 & 0.001 \\
\hline & $(0.028)$ & $(0.034)$ & $(0.036)$ & $(0.030)$ & $(0.032)$ \\
\hline \multirow[t]{2}{*}{ Ethnic Balance X Distance } & 0.012 & 0.011 & 0.031 & 0.003 & -0.009 \\
\hline & $(0.029)$ & $(0.034)$ & $(0.037)$ & $(0.033)$ & $(0.031)$ \\
\hline \multirow[t]{2}{*}{ Militant Ties X Distance } & $0.059 * *$ & $0.057 *$ & $0.081 * *$ & $0.065 * *$ & 0.014 \\
\hline & $(0.026)$ & $(0.031)$ & $(0.035)$ & $(0.031)$ & $(0.031)$ \\
\hline \multirow[t]{2}{*}{ Women \& Children X Distance } & 0.008 & 0.007 & 0.029 & 0.016 & -0.011 \\
\hline & $(0.027)$ & $(0.032)$ & $(0.034)$ & $(0.030)$ & $(0.030)$ \\
\hline \multirow[t]{2}{*}{ Distance } & $0.078 *$ & $0.125 * *$ & 0.055 & $0.078 *$ & $0.137 * * *$ \\
\hline & $(0.042)$ & $(0.054)$ & $(0.061)$ & $(0.047)$ & $(0.050)$ \\
\hline \multirow[t]{2}{*}{ OHAL } & 0.005 & 0.093 & -0.019 & -0.027 & -0.042 \\
\hline & $(0.083)$ & $(0.090)$ & $(0.090)$ & $(0.100)$ & $(0.098)$ \\
\hline \multirow[t]{2}{*}{ Refugee Exposure } & $0.104 * * *$ & $0.138 * * *$ & 0.074 & $0.088 *$ & $0.103 * *$ \\
\hline & $(0.038)$ & $(0.050)$ & $(0.050)$ & $(0.047)$ & $(0.047)$ \\
\hline \multirow[t]{2}{*}{ Kurdish } & 0.052 & -0.023 & -0.000 & $0.092 * *$ & $0.132 * * *$ \\
\hline & $(0.037)$ & $(0.042)$ & $(0.046)$ & $(0.045)$ & $(0.044)$ \\
\hline \multirow[t]{2}{*}{ Arab } & $0.056 *$ & 0.025 & 0.034 & 0.064 & $0.093 * *$ \\
\hline & $(0.034)$ & $(0.043)$ & $(0.050)$ & $(0.041)$ & $(0.041)$ \\
\hline \multirow[t]{2}{*}{ Alawite } & -0.007 & 0.042 & 0.015 & -0.053 & -0.032 \\
\hline & $(0.034)$ & $(0.044)$ & $(0.045)$ & $(0.039)$ & $(0.040)$ \\
\hline \multirow[t]{2}{*}{ CHP Supporter } & $-0.072 * *$ & $-0.118 * * *$ & $-0.083 *$ & -0.055 & -0.029 \\
\hline & $(0.034)$ & $(0.040)$ & $(0.043)$ & $(0.038)$ & $(0.039)$ \\
\hline \multirow[t]{2}{*}{ MHP Supporter } & -0.008 & -0.033 & 0.015 & -0.007 & 0.007 \\
\hline & $(0.038)$ & $(0.045)$ & $(0.049)$ & $(0.044)$ & $(0.043)$ \\
\hline \multirow[t]{2}{*}{ Kurdish Parties Supporter } & -0.036 & -0.062 & -0.022 & -0.006 & -0.035 \\
\hline & $(0.033)$ & $(0.042)$ & $(0.043)$ & $(0.037)$ & $(0.040)$ \\
\hline \multirow[t]{2}{*}{ AKP Supporter } & $0.066 * * *$ & 0.045 & $0.079 * * *$ & $0.081 * * *$ & $0.067 * *$ \\
\hline & $(0.023)$ & $(0.030)$ & $(0.030)$ & $(0.028)$ & $(0.029)$ \\
\hline \multirow[t]{2}{*}{ Constant } & -0.076 & -0.259 & 0.107 & -0.130 & $-0.456 *$ \\
\hline & $(0.206)$ & $(0.263)$ & $(0.292)$ & $(0.228)$ & $(0.241)$ \\
\hline Observations & 1077 & 1063 & 1061 & 1041 & 1031 \\
\hline R-squared & 0.24 & 0.17 & 0.18 & 0.19 & 0.26 \\
\hline
\end{tabular}

Dependent variables (0-1): Pro-intervention Attitudes (col. 1), removing Assad (col. 2), creating a safe zone (col. 3), all rebel forces (col. 4), and Islamic rebel forces (col. 5), All models include province fixed effects and additional controls: age, religiosity index, education, wealth index, sex, dummies for urban resident and for whether the interview was conducted during Ramadan (only $10 \%$ ). Robust standard errors in parentheses. Signif.: $* 10 \% * * 5 \%$ $* * * 1 \%$. 
In Figure 4, we show the marginal effect of the Militant Ties treatment close to a border crossing $\left(10^{\text {th }}\right.$ percentile, or the log of 13 kilometers $\left.^{32}\right)$ and far from a border crossing $\left(90^{\text {th }}\right.$ percentile, or the log of 245 kilometers $^{33}$ ), compared to the control group. Far from a crossing, this treatment has a positive effect on support for using force in Syria, to remove Assad, to establish a safe zone in Northern Syria, and on support for all rebels $(11,11,16$, and 13 percentage points increase, respectively, comparable to the effect of this treatment in non-border provinces). This treatment has no effect on respondents residing $13 \mathrm{~km}$ from a border crossing. What is perhaps most striking, is the differential effect of the Militant Ties treatment on support for the safe zone near and far from border crossings. This is not surprising since border areas are precisely those that would be explicitly affected based on their proximity to the proposed safe zones.

\section{Additional Robustness Checks}

In Table A-15 in the Appendix, we show that the differential effect of the Militant Ties treatment exists also for respondents from border districts compared to those who reside in non-border districts. This is consistent with our main results based on comparison of border and non-border provinces.

It is possible that the ethnic composition of border and non-border areas differs, and this may influence our findings. In the main regression, we include indicators for Kurdish, Arab, and Alawite respondents. In Table A-16 in the Appendix, we omit minority respondents, and repeat our tests only using responses of non-minority participants. The coefficient of Militant Ties is positive, however it is statistically significant only for support for removing Assad and for establishing a safe zone. The interaction term is negative, but statistically significant only for the overall support for intervention, for removing Assad, and for establishing a safe zone. Overall these results are consistent with our main findings, despite the drop in statistical significance in some cases. Excluding minority respondents decreases the number of respondents, and may account for some

\footnotetext{
${ }^{32}$ Some respondents from Kilis and Hatay fall into this category.

${ }^{33}$ This is the approximate distance of respondents from Muş to the closest border crossing.
} 
Figure 4: Marginal Effect of the Militant Ties Treatment close and far from the border

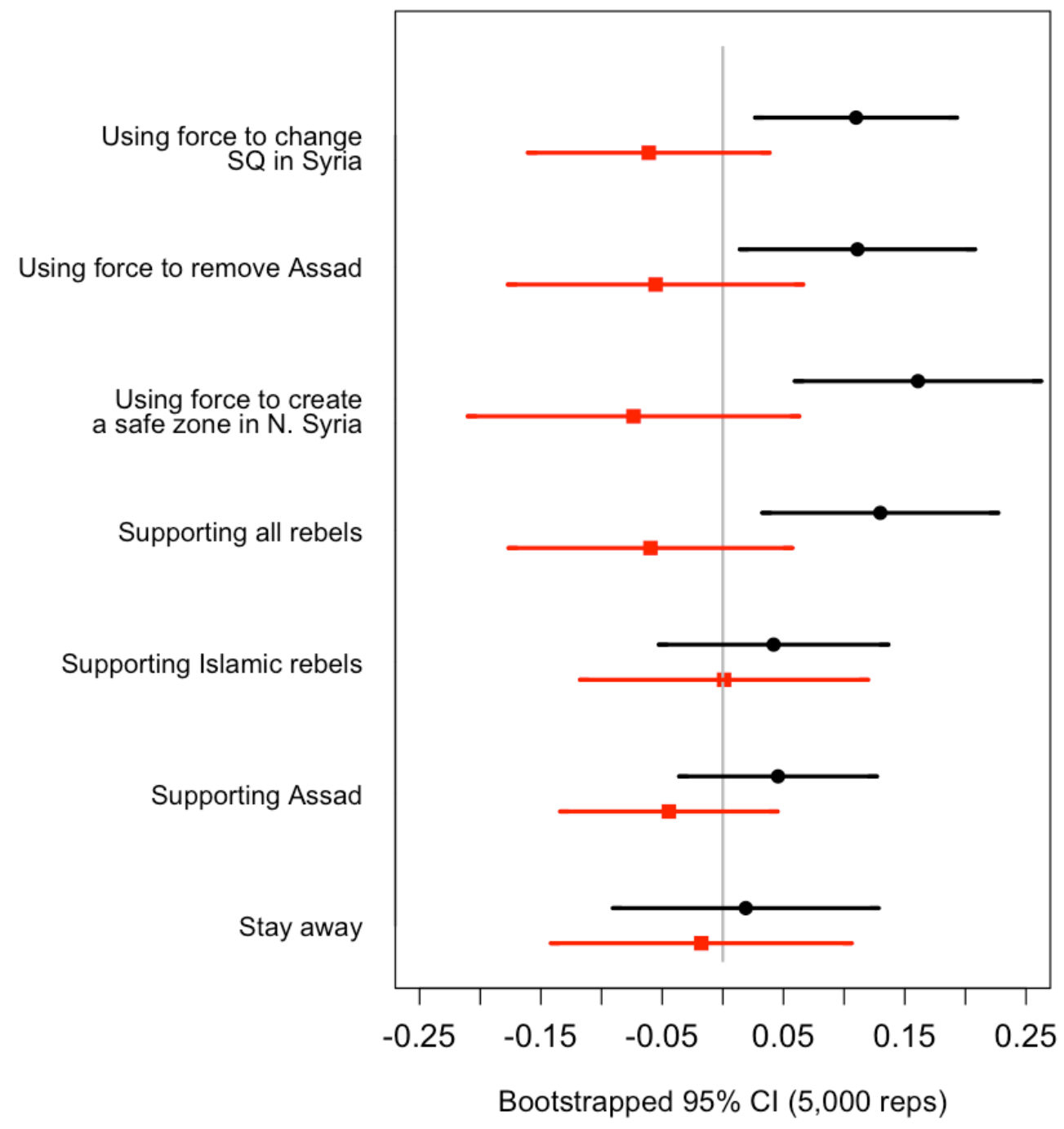

90th percentile distance to border crossing 10th percentile distance to border crossing 
loss in statistical significance.

Our findings-that the Militant Ties treatment moves mainly non-border respondents-could also be due to the border respondents being better informed about the effects of hosting refugees, and are thus not swayed by our treatments. In Table A-17 in the Appendix, we examine whether respondents in border provinces differ from those in non-border provinces in their knowledge of the number of Syrian refugees in Turkey, and find that they do not. We also find that higher exposure to Syrian refugees is not related to more accurate knowledge-in this case knowing the correct number of refugees that reside in Turkey at the time of the survey. This results suggests that heterogeneous treatment effect we find-in border and non-border provinces-is not due to better informed respondents in the former.

Another potential explanation of our findings is that the border respondents have warmer attitudes towards the refugees due to their more frequent and more positive interactions with them, and because of these warmer attitudes, our primes emphasizing refugees' potential negative effects are not effective amongst the border respondents. To explore this possibility, we ran regressions where the dependent variable is respondents' answer to a feeling thermometer question towards particular ethnic groups of Syrian refugees. As we report in Table A-18 in the Appendix, the border respondents do not show warmer or colder feelings towards Sunni, Arab, Kurdish or Alawite refugees. These results suggest that the heterogeneous treatment effects in border and non-border provinces are not due to the border respondents having warmer attitudes towards the refugees. $^{34}$

An additional possibility is whether there was selective out-migration from the border provinces due to security concerns. This could lead to baseline differences between the survey respondents by the border and those far from the border, and provide a potential alternative explanation of our findings. However, the province-level internal migration data show that border provinces in our sample have not experienced a larger outflow of residents relative to the non-border provinces. According to the data from Turkish Institute of Statistics, the out migration was lower in non-

\footnotetext{
${ }^{34} \mathrm{~A}$ related alternative explanation also suggests that respondents exposed to refugees may favor intervention since they see the high civilian costs of civil wars, and want to end them. We are thankful to a reviewer for suggesting this explanation.
} 
border provinces both in 2013 - the year before our survey - and in 2014 (2.7 vs. 3.1 percent in 2013 , and 2.8 vs 3.4 percent in 2014). ${ }^{35}$

Finally, we report the results with respect to support for specific policies of intervention using an ordered probit model, since the responses to these question are coded on an ordinal scale. Our results hold, and they are reported in Table A-19 in the Appendix.

\section{Conclusion}

We show that individuals in Turkey-a major host country-are concerned about Syrian refugees, and this leads some to want to intervene in civil war in Syria. Yet we find that only certain negative messages about refugees consistently sway attitudes in favor of intervention. In particular, emphasizing the refugees' ties with militants increases support for intervention, but only for those who live further from the border and are buffered from any potential intervention fallout. In contrast, emphasizing the economic costs or ethnic differences of the refugees has inconsistent or null effects.

Partisanship is also an important factor, as we find individuals follow cues from their party leaders (AKP and $\mathrm{CHP}$ ) in forming opinions about intervention. Likewise, the positive relationship between refugee exposure and support for intervention in Syria suggests that individuals want to take action and intervene in response to refugees' inflow. However, even after controlling for these factors, we find that information about refugees' potential ties with militants can change positions about intervention depending on the individual's vulnerability to the costs of such intervention.

We further find that the effects of reminding individuals about the negative externalities of

\footnotetext{
${ }^{35}$ It is possible that the composition of those who migrated out of border and non-border provinces may be different. Our data do not allow us to test for this possibility. However, using data from the Turkish Institute of Statistics on age and education levels of individuals who migrate out of provinces, we show that there are no significant differences in the population share of adult population and population share of college graduates that migrated out of border vs. non-border provinces in 2013 or in 2014 . The percentages of adult population who migrated out of border provinces in 2013 and 2014 are 2.4 and 2.7, while the same percentages for non-border provinces is 2.9 and 3 . The percentages of college graduates who migrated out of border provinces in 2013 and 2014 are .52 and .56, while the same percentages for non-border provinces are .64 and .73. Simple tests of difference in means show that none of these differences are significant.
} 
hosting refugees on public support for intervention vary. Locals who reside far from the border, and do not bear the costs of intervention become more supportive of intervention following information about the possibility that some refugees might have ties to militants. Conversely, locals who reside closer to the border actually slightly reduce their support for intervention when they are reminded of such ties. These findings are consistent with previous studies about how proximity is associated with preferences. In sum, which people are expected to bear the costs associated with different foreign policy options are an important determinant of public opinion. We also demonstrated that these results cannot be explained by warmer attitudes towards refugees in the vicinity of the border and by greater knowledge about the issue that weakens the effects of our treatments. Official data is also not consistent with the explanation that migration out of border areas explains these results. ${ }^{36}$

Our survey makes three important contributions to understanding support for intervention. First, we show that the public in a developing, non-US context holds principled foreign policy attitudes that reflect key partisan, and to a lesser extent, ethnic divisions about high stakes policy choices such as the Turkish intervention in Syria. Second, elite messages (primes) about refugees influence foreign policy attitudes-in particular those emphasizing the militant ties of refugees. Finally, and perhaps most importantly, these messages are moderated by proximity to the border with Syria.

Taken together, our findings suggest that purely top-down (Berinsky, 2009), or structured ideology or partisanship-based models (Rathbun, Kertzer, Reifler, Goren and Scotto, 2016) are incomplete. Exposure to the potential costs of conflict is an important determinant of attitudes. From a normative perspective, our findings are somewhat encouraging as they suggest that citizens are not myopic about foreign policy positions. Rather citizens weigh the potential benefits and costs of different policies, and how these policies may directly influence them. We argue that the question of how differential exposure to the costs of different foreign policies influences attitudes remains understudied. It further suggests that elites may not be as easily able to sway the public

\footnotetext{
${ }^{36}$ An alternative explanation may be that locals perceive the (economic) benefits from refugees to be high and perhaps do not want any intervention to disrupt this. While this is speculative, we are grateful to a reviewer pointing this alternative interpretation.
} 
on foreign policy-especially the parts of the public that have to bear the costs of foreign policy actions.

This last point has clear policy implications in the case of Turkey and the public support for Turkish interventions in Syria. Turkey is currently considering to launch a new military operation in northern Syria (Hürriyet, 2018). At the same time, some nationalist Turkish politicians are propagating the view that Syrians constitute a major economic, cultural, and security threat to Turkish state and society, and therefore, they should return to Syria (Özdağ, 2018). Our results indicate that such elite messages have a limited effect on the Turkish public support for military operations in Syria. Only those messages that emphasize Syrian refugees constituting a potential security threat should increase support for military operation among Turkish citizens living far from the border. Those closer to the border may be either not affected by these messages or become less supportive of a new operation. 


\section{References}

Acikmese, Sinem and Akin Unver. 2013. “Turk Dis Politikasi Kamuoyu Algilari Arastirmasi." available (in Turkish) at http://sites.khas.edu.tr/tdpkaa/.

Al Jazeera. 2013. "Turkey PM 'will support' Syria no-fly zone.". [Online at http: //www.aljazeera.com/news/europe/2013/05/201351076615828.html; posted 10May-2013].

Al-Shishani, Murat Batal. 2013. “Turkey and Syria's Jihadis: More than Free Passage?" Turkey Analyst 6(10).

Arsu, Sebnem. 2011. "Turkish Premier Urges Assad to Quit in Syria.". [Online at http://www.nytimes.com/2011/11/23/world/middleeast/turkish-leadersays-syrian-president-should-quit.html; posted 22-November-2011].

Barkey, Henri. 2014. “Turkey's Syria Predicament.” Survival 56(6):113-34.

Baum, Matthew A. and Philip B. K. Potter. 2008. “The Relationships Between Mass Media, Public Opinion, and Foreign Policy: Toward a Theoretical Synthesis." Annual Review of Political Science 11(1):39-65

BBC. 2017. "Turkey ends Euphrates Shield campaign in Syria.". [Online at http://www . bbc . com/news/world-middle-east-39439593; posted 30-March-2017].

Berezin, Mabel and Juan Díez-Medrano. 2008. “Distance Matters: Place, Political Legitimacy and Popular Support for European Integration." Comparative European Politics 6(1):1-32.

Berinsky, Adam J. 2007. "Assuming the Costs of War: Events, Elites, and American Public Support for Military Conflict." Journal of Politics 69(4):975-997.

Berinsky, Adam J. 2009. In Time of War: Understanding American Public Opinion from World War II to Iraq. Chicago, IL: University of Chicago Press. 
Betts, Alexander, Louise Bloom, Josiah David Kaplan and Naohiko Omata. 2017. Refugee economies: Forced displacement and development. Oxford University Press.

Blair, David and Barney Henderson. 2012. "Syria shoots down Turkish fighter jet.". [Online at http://www.telegraph.co.uk/news/worldnews/middleeast/syria/9349777/ Syria-shoots-down-Turkish-fighter-jet.html; posted 22-June-2012].

Bove, Vincenzo and Tobias Böhmelt. 2016. "Does immigration induce terrorism?" The Journal of Politics 78(2):572-588.

Burch, Jonathan. 2011. "Turkey tells Syria's Assad: Step down!". [Online at http: //www.reuters.com/article/us-syria-idUSL5E7MD0GZ20111122; posted 22November-2011].

Butler, David. 2014. " "Turkey Shoots Down Syrian Plane it Says Violated Air Space.". [Online at http://www.reuters.com/article/us-syria-crisis-airplaneidUSBREA2M0 9X20140324; posted 24-March-2014].

Card, David. 2005. "Is the new immigration really so bad?" The Economic Journal 115(507):F300F323.

Çağaptay, Soner. 2013. "Syria's War Could Inflame Turkey's Hatay Province.". [Online at http://www.washingtoninstitute.org/policy-analysis/view/syrias-warcould-inflame-turkeys-hatay-province; posted 4-April-2013].

Çetingüleç, Mehmet. 2014. "Syrian Refugees Aggravate Turkey's Unemployment Problem.". [Online at http://www.al-monitor.com/pulse/originals/2014/07/cetingulecsyrian-refugees-turkey-unemployment-illegal-work.html; posted 9-July-2014].

Center for Economic and Foreign Policy Studies (EDAM). 2012. “Turks Given Little Support for a Direct Intervention Against Syria.". Online at http: / / www . edam. org.tr/en/Fi le?id=89.

Ceritoglu, Evren, H Burcu Gurcihan Yunculer, Huzeyfe Torun and Semih Tumen. 2017. “The 
impact of Syrian refugees on natives? labor market outcomes in Turkey: evidence from a quasiexperimental design." IZA Journal of Labor Policy 6(1):5.

Choi, Seung-Whan and Idean Salehyan. 2013. "No good deed goes unpunished: refugees, humanitarian aid, and terrorism." Conflict Management and Peace Science 30(1):53-75.

Cortes, Kalena E. 2004. “Are refugees different from economic immigrants? Some empirical evidence on the heterogeneity of immigrant groups in the United States." Review of Economics and Statistics 86(2):465-480.

Del Carpio, Ximena V and Mathis Wagner. 2015. The impact of Syrians refugees on the Turkish labor market. The World Bank.

Dube, Arindrajit, Oeindrila Dube and Omar García-Ponce. 2013. “Cross-border spillover: US gun laws and violence in Mexico." American Political Science Review 107(03):397-417.

Erdoğan, Murat. 2015. Turkiye'deki Suriyeliler: Toplumsal Kabul ve Uyum Arastirmasi [Syrians in Turkey: Social Acceptance and Integration Research]. Ankara: Hacettepe Universitesi Goc ve Siyaset Arastirmalari Merkezi (HUGO) Yayinlari. Available at https://data.unhcr.org/ syrianrefugees/download.php?id=8228.

Fahim, Kareem and Sebnem Arsu. 2013. “Car Bombings Kill Dozens in Center of Turkish Town Near the Syrian Border.". [Online at http://www.nytimes.com/2013/05/12/world/ middleeast/bombings-in-turkish-border-town.html; posted 11-05-2013].

Ferris, Elizabeth. 2016. Syrian Refugees in Turkey: Challenges and Impact on Turkey's Regional Policies. In The AKP and Turkish Foreign Policy in the Middle East, ed. Zeynep N. Kaya. London: LSE Middle East Centre Collected Papers, Volume 5 pp. 25-30.

Fisk, Kerstin. 2014. "Refugee Geography and the Diffusion of Armed Conflict in Africa." Civil Wars 16(3):255-275.

Forsberg, Erika. 2014. “Transnational Transmitters: Ethnic Kinship Ties and Conflict Contagion 1946-2009." International Interactions 40(2):143-165. 
Gartner, Scott Sigmund, Gary M. Segura and Michael Wilkening. 1997. “All Politics Are Local: Local Losses and Individual Attitudes toward the Vietnam War." The Journal of Conflict Resolution 41(5):669-694.

Gelpi, Christopher, Peter D. Feaver and Jason Reifler. 2006. “Success Matters: Casualty Sensitivity and the War in Iraq." International Security 30(3):7-46.

Getmansky, Anna and Thomas Zeitzoff. 2014. "Terrorism and voting: The effect of rocket threat on voting in Israeli elections." American Political Science Review 108(03):588-604.

Gravelle, Timothy B. 2014. "Love Thy Neighbo(u)r? Political Attitudes, Proximity and the Mutual Perceptions of the Canadian and American Publics." Canadian Journal of Political Science 47(1):135-157.

Gravelle, Timothy B. 2018. "Politics, time, space, and attitudes toward US-Mexico border security." Political Geography 65:107-116.

Greenhill, Kelly M. 2011. Weapons of mass migration: forced displacement, coercion, and foreign policy. Cornell University Press.

Güler, Eren. 2014. "Syrian Refugees in Turkey Start to Work in Service Sector.". [Online at http://www.hurriyetdailynews.com/syrian-refugees-in-turkey-start-towork-in-service-sector aspx?page ID=238\&nID=68699\&NewsCat $I D=347$; posted 5-July-2014].

Holsti, Ole R. 1992. "Public Opinion and Foreign Policy: Challenges to the Almond-Lippmann Consensus Mershon Series: Research Programs and Debates." International Studies Quarterly 36(4):439-466.

Hunt, Jennifer and Marjolaine Gauthier-Loiselle. 2010. "How much does immigration boost innovation?" American Economic Journal: Macroeconomics 2(2):31-56.

Hürriyet. 2018. “Turkey intensely preparing for new operation in northern Syria: Minister.”. [On- 
line at http://www.hurriyetdailynews.com/turkey-intensely-preparing-fornew-operation-in-northern-syria-minister-139882; posted 20-December-2018].

Hürriyet Daily News. 2013. "Turkish Opposition CHP Delegation Visits al-Assad." Hürriyet March

7. Online at http://www.hurriyetdailynews.com/turkish-opposition-chpdelegation-visits-al-assad.aspx?pageID=238\&nID=42531\&NewsCat ID=338; posted 7-March-2013.

İçduygu, Ahmet. 2015. Syrian Refugees in Turkey: The Long Road Ahead. Washington, DC: migration Policy Institute - Transatlantic Council on Migration. Available at http://www. migrationpolicy.org/research/syrian-refugees-turkey-long-road-ahead.

ICG. 2013. Blurring the Borders: Syrian Spillover Risks for Turkey. Europe Report N.225. Brussels, Belgium: International Crisis Group. [Online at https://www.crisisgroup.org/middleeast-north-africa/eastern-mediterranean/syria/blurring-borderssyrian-spillover-risks-turkey; posted 30-April-2013].

Idiz, Semih. 2014. "Turkey's Syrian Refugee Problem Spirals Out of Control.". [Online at http://www.al-monitor.com/pulse/ru/originals/2014/07/idiz-turkeysyrian-refugees-local-tension-adana-istanbul.html; posted 20-July-2014].

Ifantis, Kostas. 2013. “The US and Turkey in the Fog of Regional Uncertainty." Hellenic Observatory Papers on Greece and Southeast Europe GreeSE Paper No. 73.

Johns, Robert and Graeme A. M. Davies. 2014. "Coalitions of the Willing? International Backing and British Public Support for Military Action." Journal of Peace Research 51(6):767-781.

Jorum, Emma Lundgra. 2014. "Syria's "Lost Province": The Hatay Question Returns.". [Online at http://carnegie-mec.org/diwan/54340; posted 28-January-2014].

Kalaycıoğlu, Ersin and Ali Çarkoğlu. 2007. Turkish Democracy Today: Elections, Protest and Stability in an Islamic Society. New York, NY: I.B. Tauris. 
Karol, David and Edward Miguel. 2007. "The Electoral Cost of War: Iraq Casualties and the 2004 U.S. Presidential Election." The Journal of Politics 69:633-648.

Kertzer, Joshua. 2013. “Making Sense of Isolationism: Foreign Policy Mood as a Multilevel Phenomenon." The Journal of Politics 75(1):225-240.

Kirişçi, Kemal. 1996. "Turkey and the Kurdish Safe-Haven in Northern Iraq." Journal of South Asian and Middle Eastern Studies 19(3):21-39.

Kirişçi, Kemal. 2000. “Disaggregating Turkish citizenship and immigration practices." Middle Eastern Studies 36(3):1-22.

Kreibaum, Merle. 2016. “Their suffering, our burden? How Congolese refugees affect the Ugandan population." World Development 78:262-287.

Kuhn, Theresa. 2012. “Europa ante portas: Border residence, transnational interaction and Euroscepticism in Germany and France." European Union Politics 13(1):94-117.

Larson, Eric V. 1996. Casualties and Concensus: The Historical Role of Casualties in Domestic Support for US Wars and Military Operations. Santa Monica, CA: The RAND Corporation, MR-726-RC.

Lazarev, Egor and Kunaal Sharma. 2017. “Brother or burden: An experiment on reducing prejudice toward Syrian refugees in Turkey." Political Science Research and Methods 5(2):201-219.

Letsch, Constanze. 2013. “Syrian Conflict Brings Sectarian Tensions to Turkey's Tolerant Hatay Province." The Guardian September 3. Online at https: / / www . theguardian.com/world/ 2013/sep/03/syria-crisis-threatens-turkish-tolerance; posted 3-September2013.

Liberman, Nira and Yaacov Trope. 2014. “Traversing psychological distance." Trends in Cognitive Sciences 18(7):364-369.

Lischer, Sarah Kenyon. 2005. Dangerous Sanctuaries: Refugee Camps, Civil War, and the Dilemmas of Humanitarian Aid. Ithaca, NY: Cornell University Press. 
Loescher, Gil and James Milner. 2004. “Protracted Refugee Situations and State and Regional Insecurity." Conflict, Security $\mathcal{E}$ Development 4(1):3-20.

Milton, Daniel, Megan Spencer and Michael Findley. 2013. "Radicalism of the Hopeless: Refugee Flows and Transnational Terrorism." International Interactions 39(5):621-645.

North Atlantic Treaty Organization. 2013. “NATO support to Turkey: Background and Timeline.". [Online at http://www.nato.int/cps/en/natohq/topics_92555.htm?; posted 19-February-2013].

Olson, Robert. 1995. “The Kurdish Question and Turkey's Foreign Policy, 1991-1995: From the Gulf War to the Incursion Into Iraq." Journal of South Asian and Middle Eastern Studies 19(1):1-30.

Özdağ, Ümit. 2018. “Suriyeli sığınmacilar Suriye'ye dönmeliler.”. [Online at https : / / 21 yyte . org/tr/merkezler/bolgesel-arastirma-merkezleri/orta-dogu-ve-afrikaarastirmalari-merkezi/suriyeli-siginmacilar-suriye-ye-donmeliler; posted 22-October-2018].

Paluck, Elizabeth Levy, Seth A. Green and Donald P. Green. 2018. “The Contact Hypothesis Reevaluated." Behavioural Public Policy p. 1?30.

Pamuk, Humeyra. 2014. "Turkish Military Fires Into Syria After Rocket Hits Mosque.". [Online at http://www.reuters.com/article/us-syria-crisis-turkeyidUSBREA2U0X320140331; posted 31-March-2014].

Paquin, Jonathan and Stephen M. Saideman. 2017. Foreign Intervention in Ethnic Conflicts. In Oxford Research Encyclopedia of International Studies. New York: Oxford University Press. http://oxfordre.com/internationalstudies/view/10.1093/acrefore/ $9780190846626.001 .0001 /$ acrefore-9780190846626-e-183.

Park, Bill. 2016. KRG-Turkey Relations from the KRG's Perspective. In The AKP and Turkish Foreign Policy in the Middle East, ed. Zeynep N. Kaya. London: LSE Middle East Centre Collected Papers, Volume 5 pp. 31-36. 
Rathbun, Brian C., Joshua D. Kertzer, Jason Reifler, Paul Goren and Thomas Scotto. 2016. “Taking Foreign Policy Personally: Personal Values and Foreign Policy Beliefs." International Studies Quarterly .

Rehman, Faiz Ur and Paolo Vanin. 2017. "Terrorism risk and democratic preferences in Pakistan." Journal of Development Economics 124:95-106.

Reuters. 2018. "Turkey says nearly 300,000 Syrians return home after military operations.". [Online at https://uk.reuters.com/article/uk-mideast-crisis-syriaturkey/turkey-says-nearly-300000-syrians-return-home-after-militaryoperations-idUKKCN1OLOBD; posted 22-December-2018].

Roberts, Adam. 1999. “NATO's 'Humanitarian War' Over Kosovo." Survival 41(3):59-83.

Saideman, Stephen M. 2012. The ties that divide: Ethnic politics, foreign policy, and international conflict. Columbia University Press.

Sak, Güven. 2014. "Of Fake Housing Bubbles and Syrian Refugees.". [Online at http://www.tepav.org.tr/en/blog/s/4909/Oftfake+housing+bubbles+and+ Syrian+refugees; posted 6-Spetember-2014].

Salehyan, Idean. 2008. "The Externalities of Civil Strife: Refugees as a Source of International Conflict." American Journal of Political Science 52(4):787-801.

Salehyan, Idean and Kristian Skrede Gleditsch. 2006. "Refugees and the Spread of Civil War." International Organization 60:335-366.

Sanchez, Raf. 2012. "Barack Obama 'Red Line' Warning Over Chemical Weapons in Syria." The Telegraph August 20. Online at http://www.telegraph.co.uk/news/worldnews/ middleeast/syria/9488314/Barack-Obama-red-line-warning-over-chemicalweapons-in-Syria.html; posted 20-August-2012.

Shaheen, Kareem. 2016. "Turkey Sends Tanks into Syria in Operation Aimed at ISIS and Kurds." The Guardian August. [Online at https : / www . theguardian.com/world/2016/aug/24/ 
turkey-launches-major-operation-against-isis-in-key-border-town; posted 24-August-2016].

Shaheen, Kareem. 2018. "Turkey Starts Ground Incursion into Kurdish-controlled Afrin in Syria." The Guardian January. [Online at https://www.theguardian.com/world/2018/jan/ 21/turkey-starts-ground-incursion-into-kurdish-controlled-afrin-insyria; posted 21-January-2018].

Shaver, Andrew and Yang-Yang Zhou. 2015. “Questioning refugee camps as sources of conflict." Unpublished manuscript. Retrieved from https: / / scholar.princeton.edu/sites/ default/files/ashaver/files/refugees_conflict_final.pdf.

Stack, Liam. 2011. "In Slap at Syria, Turkey Shelters Anti-Assad Fighters.". [Online at http://www. nytimes.com/2011/10/28/world/europe/turkey-is-shelteringantigovernment-syrian-militia.html; posted 27-October-2011].

Taşpınar, Ömer. 2012. “Turkey's Strategic Vision and Syria.” The Washington Quarterly 35(3):127140.

Tatah, Lambed, Tefera Darge Delbiso, Jose Manuel Rodriguez-Llanes, Julita Gil Cuesta and Debarati Guha-Sapir. 2016. "Impact of refugees on local health systems: a difference-in-differences analysis in Cameroon." PloS one 11(12):e0168820.

Taylor, J Edward, Mateusz J Filipski, Mohamad Alloush, Anubhab Gupta, Ruben Irvin Rojas Valdes and Ernesto Gonzalez-Estrada. 2016. "Economic impact of refugees." Proceedings of the National Academy of Sciences 113(27):7449-7453.

The German Marshall Fund of the United States. 2015. "Turkish Perceptions Survey.". Online at http://www.gmfus.org/sites/default/files/TurkeySurvey_2015_web1.pdf.

UNHCR. 2014. “UNHCR Turkey Syrian Refugee Daily Sitrep, June 6.” http: // data • unher. org/syrianrefugees/download.php?id=6183. Accessed: 2016-11-13. 
US Department of State. 2015. “Syria Border Crossings Dataset." Humanitarian Information Unit. URL: https://data.humdata.org/dataset/syria-border-crossings

Weidmann, Nils B., Patrick Kuhn and Varja Nikolic. 2007. "Refugees as Local Catalysts of Conflict?" Working Paper.

Weiner, Myron. 1996. “Bad Neighbors, Bad Neighborhoods: An Inquiry into the Causes of Refugee Flows." International Security 21(1):5-42.

Whitaker, Beth Elise. 2003. "Refugees and the Spread of Conflict: Contrasting Cases in Central Africa." Journal of Asian and African Studies 38(2-3):211-231.

Wolfe, Lauren. 2017. "There Are No Real 'Safe Zones,' and There Never Have Been.". https://foreignpolicy.com/2017/03/30/there-are-no-real-safe-zonesand-there-never-have-been-syria-iraq-bosnia-rwanda/.

Yassin-Kassab, Robin. 2011. "The Fall of the House of Assad.". [Online at http:// foreignpolicy.com/2011/06/10/the-fall-of-the-house-of-assad-2/; posted 10-June-2011].

Yıld1z, Güney. 2016. Turkey's Rojava Policy? In The AKP and Turkish Foreign Policy in the Middle East, ed. Zeynep N. Kaya. London: LSE Middle East Centre Collected Papers, Volume 5 pp. 4043.

Yılmaz, Hakan. 2014. “Türkiye'de Kimlikler, Kürt Sorunu ve Çözüm Süreci: Algılar ve Tutumlar [Identities, Kurdish Question and the Solution Process in Turkey: Public Perceptions and Attitudes].". [Online at http://www.hakanyilmaz.info/yahoo_site_admin/assets/ docs/OSI_Yurttaslik_2014_Cozum_Sureci_Sunum_Basin_v08.259182726.pdf].

Y1lmaz, Nuh. 2013. "Syria: The View From Turkey.". [Online at http://www.ecfr.eu/ article/commentary_syria_the_view_from_turkey139; posted 19-June-2013].

Zeitzoff, Thomas. 2014. "Anger, exposure to violence, and intragroup conflict: A 'Lab in the Field' experiment in Southern Israel." Political Psychology 35(3):309-335. 